\title{
A REVIEW OF WINE AND WINE TOURISM PRESENCE IN THE SCIENTIFIC PAPERS IN JOURNALS IN THE FIELD OF TOURISM
}

\author{
Slavica Anđelić ${ }^{1}$, Dušan Garabinović ${ }^{2}$, Goran Šormaz ${ }^{3}$ \\ *Corresponding author E-mail: dusan.garabinovic.032@gmail.com
}

\begin{abstract}
A R T I C LE IN F O
A B S T R A C T

Review Article

Received: 15 July 2019

Accepted: 10 October 2019

doi:10.5937/ekoPolj1904055A

UDC 663.21:[338.48-6:641/.642

Keywords:

wine, tourism, wine tourism, enotourism, wineries, literature overview

The aim of this paper is to indicate the representation of

JEL: L66, L83, Z30 the papers related to wine and wine (eno) tourism in the scientific journals in the field of tourism from the Journal Citation Reports (JCR) list, with the Impact Factor (IF) Clarivate Analytics. Fifteen journals have been analyzed on the basis of the phrase presence related to wine and wine tourism in titles, keywords and abstracts. 91 papers have been singled out, with their review per journal, as well as summary of publication frequency per year. The significance of wine and wine tourism in the entire tourism is emphasized through the tendency of their increasing presence in the most relevant scientific journals in the field. This paper creates a foundation for the authors interested in detailed research of the papers published so far, and therefore further development of the scientific and research activities related to wine and wine tourism.
\end{abstract}

(C) 2019 EA. All rights reserved.

\section{Introduction}

Represented in proverbs, customs, beliefs, thoughts of famous people and those less famous, as well as songs, wine has always been "the initiator" for the people. It has always been a component of human life. The relation towards wine has directed people in many areas of life, determining their view of themselves to a certain point, as well as the environment and the world we live in. Wine has multiple meanings. It is not just a product similar to other alcoholic drinks. It is "a person living", just as any other living

1 Slavica Anđelić, PhD, Higher business school of vocational studies "Prof. dr Radomir Bojković", Topličina 12, 37000 Kruševac, Republic of Serbia, Phone: +38162485274, E-mail: slavica.andjelic@indmanager.edu.rs, ORCID ID: https://orcid.org/0000-00034021-0822

2 Dušan Garabinović, MSc, Higher business school of vocational studies "Prof. dr Radomir Bojković", Topličina 12, 37000 Kruševac, Republic of Serbia, Phone: +381643929596, E-mail: dusan.garabinovic.032@gmail.com, ORCID ID: https://orcid.org/0000-00026247-3060

3 Goran Šormaz, Higher business school of vocational studies "Prof. dr Radomir Bojković", Topličina 12, 37000 Kruševac, Republic of Serbia, Phone: +381698206454, E-mail: goran. sormaz@indmanager.edu.rs, ORCID ID: https://orcid.org/0000-0001-6473-1062

http://ea.bg.ac.rs 
being. There has always been something connected to wine, it has been the center of various events in spiritual, religious, cultural, culinary terms, entertainment, etc. Wine is complexity in simplicity, a phenomenon of human existence. The history of wine is a history of mankind at the same time. The charm of getting to know this ancient yet always trendy beverage can be found in this fact. Therein lies the basis for the appearance of tourist trends related to wine, and they managed to become singled out and differentiated as a separate type of tourism through their attractions and specific points, simultaneously related to many others (gastro, rural, etc) - wine tourism or enotourism.

"Wine is the beverage resulting exclusively from the partial or complete alcoholic fermentation of fresh grapes, whether crushed or not, or of grape must. Its actual alcohol content shall not be less than 8.5\% vol" (International Organisation of Vine and Wine, 2017, I.1.3-1). "Nevertheless, taking into account climate, soil, vine variety, special qualitative factors or traditions specific to certain vineyards, the minimum total alcohol content may be able to be reduced to $7 \%$ vol. by legislation particular to the region considered" (International Organisation of Vine and Wine, 2017, I.1.3-1).

According to the International Organisation of Vine and Wine, vineyard surface area in the world in 2016 amounted to 7,463,909 ha (a reduction compared to $2001-7,786,462$ ha), while wine production was 269,012 (an increase compared to 2001 - 265,523), wine exports 103,832 (an increase compared to 2001 - 65,151), wine imports 104,027 (an increase compared to 2001 -61,095), wine consumption 244,421 (an increase compared to 2001 - 227,642), whereas the unit is $1000 \mathrm{hl}$ (International Organisation of Vine and Wine - OIV). In comparison to the beginning of the $21^{\text {st }}$ century, there was an increase in imports (70.27\%), exports (59.37\%), production (1.31\%) and wine consumption $(7.37 \%)$, while the vineyard surface area was reduced for $4.14 \%$ at the same time. According to (International Organisation of Vine and Wine, 2019), vineyard surface area was around 7,429 thousand ha (continued reduction), production was around 292,300 (an increase) and wine consumption was around 246,000 (an increase), unit $1000 \mathrm{hl}$ (forecasted data) in 2018 (pp. 5-11).

According to International Organisation of Vine and Wine (2019), a) the countries with the largest vineyard surface space are Spain, China, France, Italy and Turkey; b) the countries as the biggest wine producers are Italy, France, Spain, the USA and Argentina; c) the countries with the largest wine consumption (consummation) are the USA, France, Italy, Germany and China (pp. 5-11).

"Wine tourism can be defined as visitation to vineyards, wineries, wine festivals and wine shows for which grape wine tasting and/or experiencing the attributes of a grape wine region are the prime motivating factors for visitors" (Hall, Longo, Mitchell \& Johnson, 1996). Wine tourism can also be considered as a type of rural tourism, confirmed by Cvijanović \& Ružić (2017) as well. The importance of wine tourism in the economic development of the rural areas is also clear from the fact that the $3^{\text {rd }}$ UNWTO Global Conference on Wine Tourism held in Chisinau (Moldova) on $6^{\text {th }}-$ $7^{\text {th }}$ September 2018 directed its activities towards "Wine Tourism as a Tool for Rural Development” (3rd UNWTO Global Conference on Wine Tourism). 
It is obvious that aforementioned countries with the largest vineyard surface area and production also have the greatest potential for wine tourism development. Still, there is a question of whether everything is in area and production scope. The above-mentioned elements are important in terms of the economic effects that arise from product placement in the market, especially the foreign market, through exports. On the other hand, wine areas should be singled out by some particularity in terms of service sector development, i.e. integrated sector of production and services. This kind of wine areas, destinations as well as individual service providers' differentiation in the field of wine and wine tourism represent a necessary marketing strategy in order to attract tourists. Therefore, wine tourism is the foundation for the emergence of the "silent" export, the kind that could have significant advantages in comparison to the traditional (classical) export type, especially through cost reduction. All things considered, along with the particularities that wine tourism possesses, make this area of tourism very interesting for scientific and professional studies both on supply and demand sides.

The subject of this paper is an overview of the representation of wine and wine tourism in scientific papers in selected journals in the field of tourism. Therefore, this paper is trying to offer the answer to the following question: "What is the significance of wine in the scientific research in the field of tourism?". The aim of this paper is to point out the number of papers related to wine and wine tourism in the scientific journals in the field of tourism that are listed in the JCR list (have Impact Factor - IF), to highlight the contribution of these papers, and to determine the frequency of words in the keywords listed in analyzed papers.

\section{A review of similar research}

López-Guzmán, García, Rodríguez (2013) offer a review of the scientific research on wine tourism in Spain according to the autonomous regions. Sánchez, García \& del Río (2016) determined that there were $14 \mathrm{PhD}$ thesis related to wine tourism defended from 2008 to 2014 - in Spain (8; 57.14\%), England (3; 21.41\%), Portugal $(2 ; 14.29 \%)$ and France $(1 ; 7.14 \%)$ (p. 191).

On the basis of the analysis conducted by Carlsen (2004), we can draw a conclusion that there is a dual approach (wine industry production and service orientation) that should be integrated into a unity as soon as possible. Thereby, five key issues important for all wine regions and wineries are: 1) "How do successful wineries manage to make the transition from a supply-led to a demand-driven business environment?, 2) Does wine tourism enable wineries to become price-makers instead of price-takers? 3) Within a wine region, how and when does the locus of economic activity shift from wine production to tourism over time? 4) How do wineries and wine regions diversify their products and services to meet the changing needs of visitors? 5) What is the relative importance of capital growth compared to profit as wealth creation activities in wine regions?" (Carlsen, 2004, pp. 8-9). 
Montella (2017) provides an overview of works related to wine tourism and sustainability (43 papers (p. 3)). It also concludes that the majority of works are related to new wine producing countries (if the work relates to a specific country), and that more than half of the works were published after 2006 (p. 3). A more detailed analysis of the presence of sustainable (wine) tourism in the literature, emerging traits (eg "from the literature it emerges that sustainable wine tourism is strongly linked to the culture and distinctive traits of the local community and place" (p. 5)), motivations and drivers and geographical distribution and trends (pp. 4-7).

Sánchez, Del Río \& García (2017) determined that there were 118 articles published in the Web of Science (WoS) and 191 in Scopus until 2014, and they all refer to wine tourism (p. 9). "The Scopus database was the first to incorporate the concept of wine tourism in 1984 and it contains the most records" (Sánchez, Del Río \& García, 2017, p. 11). They emphasize that "in the last five years (2010-2014), more than $60 \%$ of wine tourism papers contained in Wos and Scopus have been published, 72 and 117 articles respectively" (Sánchez, Del Río \& García, 2017, p. 11). The author with the largest number of papers is Alonso, A. D. (Scopus 21, WoS 10), whereas, on the other hand, the most productive journal (with the largest number of papers) is Tourism Management (WoS 13, 11.02\%; Scopus 12, 6.28\%), the only one with a two-digit number of papers (Sánchez, Del Río \& García, 2017, pp. 12-13).

Gómez, Pratt \& Molina (2018) carried out an extensive research on the presence of wine tourism in the scientific papers from 1995 to 2014 (176 papers), emphasizing, at the same time, that the framework for wine research has been expanded with two new fields compared to the previous formulations, and they are "regional development and the experiential wine tourist".

Mitchell \& Hall (2006) offer a review of "the Australian research into winery visitation", "the research on New Zealand winery visitation", and "other international research into winery visitation" (North America, Europe, Southern Hemisphere, other), whereas they concluded that (at that moment) "Australia and New Zealand are the source of the vast majority of published literature on winery visitation" (Australia 38\%, New Zealand 31\%), followed by prevailing North America (pp. 308-311).

\section{Materials and methods}

The research is conducted on the $6^{\text {th }}$ and $7^{\text {th }}$ July 2019, on the sample of 15 scientific journals in the field of tourism (journals which names refer directly to the words "tourism", "tourist") from the Journal Citation Reports (Clarivate Analytics, 2018) list, with the Impact Factor (IF). The choice of these journals adds to the significance of the analysis, considering that we speak of the currently best journals in the field. Thus, the analysis of the wine and wine tourism presence in the published papers is improved additionally, indicating the tendencies for the study in this field at the highest, world level. The review of the analyzed journals along with their Impact Factor (IF) is offered in the table below (Table 1.). 
Table 1. The analyzed journals

\begin{tabular}{|l|l|l|l|}
\hline No. & \multicolumn{1}{|c|}{ Journal name } & \multicolumn{1}{|c|}{ ISSN } & \multicolumn{1}{|c|}{\begin{tabular}{c} 
(2017) \\
\hline
\end{tabular}} \\
\hline & Tourism Management & $0261-5177$ & 5.921 \\
\hline & Annals of Tourism Research & $0160-7383$ & 5.086 \\
\hline & Current Issues in Tourism & $1368-3500$ & 3.462 \\
\hline & Journal of Sustainable Tourism & $0966-9582$ & 3.329 \\
\hline & Journal of Hospitality and Tourism Research & $1096-3480$ & 2.685 \\
\hline & International Journal of Tourism Research & $1099-2340$ & 2.449 \\
\hline & Tourism Geographies & $1461-6688$ & 2.068 \\
\hline & Journal of Travel and Tourism Marketing & $1054-8408$ & 1.975 \\
\hline & Tourism Management Perspectives & $2211-9736$ & 1.779 \\
\hline & Tourist Studies & $1468-7976$ & 1.537 \\
\hline & Asia Pacific Journal of Tourism Research & $1094-1665$ & 1.352 \\
\hline & Journal of Hospitality, Leisure, Sport and Tourism Education & $1473-8376$ & 1.265 \\
\hline & Scandinavian Journal of Hospitality and Tourism & $1502-2250$ & 1.235 \\
\hline & Journal of Tourism and Cultural Change & $1476-6825$ & 1.105 \\
\hline & Tourism Economics & $1354-8166$ & 0.942 \\
\hline
\end{tabular}

Source: The authors' research based on Clarivate Analytics (2018)

The journals were analyzed using the database of the papers available online: Science Direct (Annals of Tourism Research, Journal of Hospitality, Leisure, Sport \& Tourism Education, Tourism Management Perspectives, Tourism Management), SAGE Journals (Tourist Studies, Tourism Economics, Journal of Hospitality \& Tourism Research), Taylor \& Francis Online (Asia Pacific Journal of Tourism Research, Current Issues in Tourism, Journal of Sustainable Tourism, Journal of Tourism \& Cultural Change, Journal of Travel \& Tourism Marketing, Scandinavian Journal of Hospitality \& Tourism, Tourism Geographies) and Wiley Online Library (International Journal of Tourism Research).

The analysis refers to the establishment of the phrases related to wine and wine tourism presence (wine, wine tourism, wine tourist, enotourism, winery, etc.) in the titles, keywords and paper abstracts (book/literature reviews, conference reports, editorials, discussion forums etc. excluded). This type of analysis has been chosen because the authors regard that the search phrase is not of great significance unless it is in the title, keywords or paper abstract, even though it can be found in the paper itself. Evidently, one of the conditions for the selection of the papers in this review has been that, in addition to the presence of the above-mentioned words and phrases, the paper's theme is related to wine and its role in tourism, at least to a certain extent (not analyzed papers where the wine, wine tourism etc. were used in another/alternative/transferred meaning).

This review also considers the papers published online at the time the research was conducted ( $6^{\text {th }}$ and $7^{\text {th }}$ July 2019), including several papers from 2019. 
After determining the papers, the papers were individually analyzed and a brief explanation of their scientific and professional contribution was given in the tables. In this way, the essence of each of the papers related to wine and wine tourism within the analyzed journals is presented. Also, the most common authors of the analyzed papers have been identified.

The frequency of words in keywords was then determined (words of the same meaning were observed together) and presented a) by journals, b) by time periods, and c) in total. Hall (2011) giving a bibliometric analysis through performance indicators and databases states that one of the three groups of performance metrics is "productivity metrics, which includes metrics such as number of (cited) papers, number of papers per academic year, number of papers per individual author" (p. 21). This paper meets the stated group of productivity metrics with the exception of the number of citations.

\section{Results and discussions}

It is established that 13 out of 15 journals $(86.67 \%)$ selected for the analysis contain at least one paper directly related to wine and wine tourism to a lesser or greater extent. The total of such papers was 91, indicating the average number of papers as 6.07, median 4, mode 2, standard deviation 6.01, minimum 0 (Tourist Studies, Journal of Hospitality, Leisure, Sport \& Tourism Education), maximum 20 (Journal of Travel and Tourism Marketing), as is the range. On the basis of the aforementioned, it is obvious that the Journal of Travel \& Tourism Marketing has the greatest share in the total number of papers $(21.98 \%)$, while only three more journals have a two-digit share (Tourism Management $-16.48 \%$, Journal of Hospitality and Tourism Research $-12.09 \%$, International Journal of Tourism Research $-12.09 \%$ ). If only the journals with the papers on wine/wine tourism are taken into account (13 journals), the average number of the papers per journal is 7, median 5, mode 2, standard deviation 5.92, minimum number 1 , maximum 20, with rank 19. All previous numbers are rounded to two decimal places.

There is a total of 74 papers with wine/wine tourism in the title, which is a significant percentage $(81.32 \%)$ compared to the established number of papers on the subject. The average number of the papers per all the analyzed journals (15) is 4.93 , median 3 , mode 2 , standard deviation 5.01, minimum 0 , maximum 17 , as is the range (17). There is a complete match $(100 \%)$ of all the papers referring to wine/wine tourism and the titles in case of 6 journals $(40.00 \%$ of the total number of journals), while the lowest percentage is $40.00 \%$. All previous numbers are rounded to two decimal places.

The review of the papers on wine and wine tourism per journal can be seen in the following table (Table 2.). 
Table 2. The review of the number of papers on wine and wine tourism per journal

\begin{tabular}{|c|c|c|c|c|}
\hline \multirow[b]{2}{*}{ Journal name } & \multicolumn{4}{|c|}{ Number of papers } \\
\hline & $\begin{array}{l}\text { Title } \\
\text { (No) }\end{array}$ & Title (\%) & $\begin{array}{l}\text { Total } \\
\text { (No) }\end{array}$ & Total (\%) \\
\hline Tourism Management & 13 & $86.67 \%$ & 15 & $16.48 \%$ \\
\hline Annals of Tourism Research & 2 & $40.00 \%$ & 5 & $5.49 \%$ \\
\hline Current Issues in Tourism & 7 & $77.78 \%$ & 9 & $9.89 \%$ \\
\hline Journal of Sustainable Tourism & 2 & $100.00 \%$ & 2 & $2.20 \%$ \\
\hline Journal of Hospitality and Tourism Research & 8 & $72.73 \%$ & 11 & $12.09 \%$ \\
\hline International Journal of Tourism Research & 9 & $81.82 \%$ & 11 & $12.09 \%$ \\
\hline Tourism Geographies & 2 & $100.00 \%$ & 2 & $2.20 \%$ \\
\hline Journal of Travel and Tourism Marketing & 17 & $85.00 \%$ & 20 & $21.98 \%$ \\
\hline Tourism Management Perspectives & 3 & $100.00 \%$ & 3 & $3.30 \%$ \\
\hline Tourist Studies & 0 & - & 0 & - \\
\hline Asia Pacific Journal of Tourism Research & 4 & $100.00 \%$ & 4 & $4.40 \%$ \\
\hline $\begin{array}{l}\text { Journal of Hospitality, Leisure, Sport and Tourism } \\
\text { Education }\end{array}$ & 0 & - & 0 & - \\
\hline Scandinavian Journal of Hospitality and Tourism & 1 & $100.00 \%$ & 1 & $1.10 \%$ \\
\hline Journal of Tourism and Cultural Change & 1 & $100.00 \%$ & 1 & $1.10 \%$ \\
\hline Tourism Economics & 5 & $71.43 \%$ & 7 & $7.69 \%$ \\
\hline TOTAL & 74 & $81.32 \%$ & 91 & $100.00 \%$ \\
\hline
\end{tabular}

Source: The authors' research

In order to get a systematic insight into the papers on wine and wine tourism published so far, a review of the papers per each journal individually will be offered below, whereas the papers are ordered per year of publishing (starting from the earliest paper published).

The review of the papers on wine and wine tourism in the Tourism Management journal is offered in the table below (Table 3.).

Table 3. The review of the papers on wine and wine tourism in Tourism Management

\begin{tabular}{|l|l|l|l|l|}
\hline Authors & Year & Title of the paper & $\begin{array}{l}\text { Volume } \\
\text { (Issue), } \\
\text { Pages }\end{array}$ & Comment/Description \\
\hline Telfer, D. J. & 2001 & $\begin{array}{l}\text { Strategic alliances along } \\
\text { the Niagara wine route }\end{array}$ & $\begin{array}{l}22(1), \\
21-30\end{array}$ & $\begin{array}{l}\text { The author emphasizes the importance } \\
\text { of cooperation for the successful } \\
\text { development of the region (Niagara) } \\
\text { as a wine tourism destination. }\end{array}$ \\
\hline $\begin{array}{l}\text { Charters, } \\
\text { S., \& Ali- } \\
\text { Knight, J. }\end{array}$ & 2002 & Who is the wine tourist? & $\begin{array}{l}\text { 23(3), } \\
311-319\end{array}$ & $\begin{array}{l}\text { The authors propose a three- } \\
\text { dimensional model (a) purpose of } \\
\text { visit, b) general tourist motivation } \\
\text { and c) relationship to other tourist } \\
\text { activities) by which specific tourist } \\
\text { activities can be identified. The } \\
\text { impact of geographical and cultural } \\
\text { differences on segmentation is } \\
\text { highlighted. }\end{array}$ \\
\hline
\end{tabular}




\begin{tabular}{|c|c|c|c|c|}
\hline Authors & Year & Title of the paper & $\begin{array}{l}\text { Volume } \\
\text { (Issue), } \\
\text { Pages } \\
\end{array}$ & Comment/Description \\
\hline Bruwer, J. & 2003 & $\begin{array}{l}\text { South African wine routes: } \\
\text { some perspectives on the } \\
\text { wine tourism industry's } \\
\text { structural dimensions and } \\
\text { wine tourism product }\end{array}$ & $\begin{array}{l}24(4), \\
423-435\end{array}$ & $\begin{array}{l}\text { The author emphasizes: a) the } \\
\text { structural dimensions of the wine } \\
\text { industry and b) the characteristics of } \\
\text { wine tourism products in relation to } \\
\text { South African wine routes. }\end{array}$ \\
\hline Hall, C. M. & 2005 & $\begin{array}{l}\text { Biosecurity and wine } \\
\text { tourism }\end{array}$ & $\begin{array}{l}26(6), \\
931-938\end{array}$ & $\begin{array}{l}\text { The author emphasizes (New } \\
\text { Zealand): a) the utility of present } \\
\text { customs declaration forms is } \\
\text { questionable, b) the need to adapt } \\
\text { biosecurity strategies }\end{array}$ \\
\hline $\begin{array}{l}\text { Getz, D., \& } \\
\text { Brown, G. }\end{array}$ & 2006 & $\begin{array}{l}\text { Critical success factors for } \\
\text { wine tourism regions: a } \\
\text { demand analysis }\end{array}$ & $\begin{array}{l}27(1) \\
146-158\end{array}$ & $\begin{array}{l}\text { "It was determined that highly } \\
\text { motivated, long-distance wine } \\
\text { tourists prefer destinations offering } \\
\text { a wide range of cultural and outdoor } \\
\text { attractions." (Calgary, Canada) }\end{array}$ \\
\hline Sparks, B. & 2007 & $\begin{array}{l}\text { Planning a wine tourism } \\
\text { vacation? Factors that } \\
\text { help to predict tourist } \\
\text { behavioural intentions }\end{array}$ & $\begin{array}{l}28(5) \\
1180- \\
1192\end{array}$ & $\begin{array}{l}\text { "Perceived control, together with } \\
\text { past attitude predicted intentions } \\
\text { to take a vacation to a wine region. } \\
\text { Wine/food involvement, normative } \\
\text { influences and three wine expectancy- } \\
\text { value (attitudinal) dimensions also } \\
\text { contribute to intention to take a } \\
\text { vacation to a wine region." (Australia) }\end{array}$ \\
\hline $\begin{array}{l}\text { Galloway, } \\
\text { G., Mitchell, } \\
\text { R., Getz, D., } \\
\text { Crouch, G., } \\
\text { \& Ong, B. }\end{array}$ & 2008 & $\begin{array}{l}\text { Sensation seeking and the } \\
\text { prediction of attitudes and } \\
\text { behaviours of wine tourists }\end{array}$ & $\begin{array}{l}29(5) \\
950-966\end{array}$ & $\begin{array}{l}\text { The authors examined "whether, } \\
\text { compared with socio-economic } \\
\text { variables, the personality variable } \\
\text { sensation seeking adds to the ability to } \\
\text { predict differences in various attitudes } \\
\text { and behaviours of wine tourists". }\end{array}$ \\
\hline $\begin{array}{l}\text { Gross, M. J., } \\
\text { \& Brown, G. }\end{array}$ & 2008 & $\begin{array}{l}\text { An empirical structural } \\
\text { model of tourists and } \\
\text { places: Progressing } \\
\text { involvement and place } \\
\text { attachment into tourism } \\
\end{array}$ & $\begin{array}{l}29(6) \\
1141- \\
1151\end{array}$ & $\begin{array}{l}\text { The authors have shown that the } \\
\text { combined use of a) involvement and } \\
\text { b) place attachment is applicable in } \\
\text { tourism. (South Australia) }\end{array}$ \\
\hline $\begin{array}{l}\text { March, R., \& } \\
\text { Wilkinson, I. }\end{array}$ & 2009 & $\begin{array}{l}\text { Conceptual tools for } \\
\text { evaluating tourism } \\
\text { partnerships }\end{array}$ & $\begin{array}{l}30(3), \\
455-462\end{array}$ & $\begin{array}{l}\text { The authors offer a method for } \\
\text { "investigating and conceptualizing } \\
\text { network relationships in a regional } \\
\text { tourism district". (Hunter Valley, } \\
\text { Australia) }\end{array}$ \\
\hline $\begin{array}{l}\text { Mason, } \\
\text { M. C., \& } \\
\text { Paggiaro, A. }\end{array}$ & 2012 & $\begin{array}{l}\text { Investigating the role of } \\
\text { festivalscape in culinary } \\
\text { tourism: The case of food } \\
\text { and wine events }\end{array}$ & $\begin{array}{l}33(6) \\
1329- \\
1336\end{array}$ & $\begin{array}{l}\text { The authors conclude that } \\
\text { "festivalscape and emotions } \\
\text { have significant direct effects on } \\
\text { satisfaction", while "effects of } \\
\text { festivalscape on visitors' future } \\
\text { behavior are only indirect and } \\
\text { mediated by satisfaction". (Italian } \\
\text { festival "Friuli DOC") }\end{array}$ \\
\hline
\end{tabular}




\begin{tabular}{|c|c|c|c|c|}
\hline Authors & Year & Title of the paper & $\begin{array}{l}\text { Volume } \\
\text { (Issue), } \\
\text { Pages } \\
\end{array}$ & Comment/Description \\
\hline $\begin{array}{l}\text { Quintal, V. } \\
\text { A., Thomas, } \\
\text { B., \& Phau, } \\
\text { I. }\end{array}$ & 2015 & $\begin{array}{l}\text { Incorporating the } \\
\text { winescape into the theory } \\
\text { of planned behaviour: } \\
\text { Examining 'new world' } \\
\text { wineries }\end{array}$ & $\begin{array}{l}46 \\
596-609\end{array}$ & $\begin{array}{l}\text { The authors concluded that } \\
\text { "winescape service staff and } \\
\text { complementary product had } \\
\text { significant effects on the wine tourist } \\
\text { attitude toward the winery", and that } \\
\text { "winescape service and wine value } \\
\text { were also significant attributes in } \\
\text { influencing the wine tourist attitude". } \\
\text { (Australia and USA) }\end{array}$ \\
\hline $\begin{array}{l}\text { Gomez, M., } \\
\text { Lopez, C., \& } \\
\text { Molina, A. }\end{array}$ & 2015 & $\begin{array}{l}\text { A model of tourism } \\
\text { destination brand equity: } \\
\text { The case of wine tourism } \\
\text { destinations in Spain }\end{array}$ & $\begin{array}{l}51 \\
210-222\end{array}$ & $\begin{array}{l}\text { The authors propose "a model for the } \\
\text { design of origin (DO) brand image } \\
\text { and destination image on brand } \\
\text { equity of wine tourism destinations } \\
\text { and examining these effects on two } \\
\text { stakeholder groups, winery managers } \\
\text { and winery visitors". } \\
\end{array}$ \\
\hline $\begin{array}{l}\text { Byrd, E. T., } \\
\text { Canziani, B., } \\
\text { Hsieh, Y. C. } \\
\text { J., Debbage, } \\
\text { K., \& } \\
\text { Sonmez, S. }\end{array}$ & 2016 & $\begin{array}{l}\text { Wine tourism: Motivating } \\
\text { visitors through core and } \\
\text { supplementary services }\end{array}$ & $\begin{array}{l}52, \\
19-29\end{array}$ & $\begin{array}{l}\text { The authors found that "the } \\
\text { importance of customer service was } \\
\text { found to be the primary predictor of } \\
\text { intentions for repeat visitation". }\end{array}$ \\
\hline $\begin{array}{l}\text { Xu, S., } \\
\text { Barbieri, C., } \\
\text { Anderson, } \\
\text { D., Leung, Y. } \\
\text { F., \& Rozier- } \\
\text { Rich, S. }\end{array}$ & 2016 & $\begin{array}{l}\text { Residents' perceptions of } \\
\text { wine tourism development }\end{array}$ & $\begin{array}{l}55, \\
276-286\end{array}$ & $\begin{array}{l}\text { Residents have a neutral attitude } \\
\text { towards wineries, while "residents' } \\
\text { socio-demographics and level } \\
\text { of wine enthusiasm, as well as } \\
\text { the comprehensiveness of wine } \\
\text { trails' tourism amenities were } \\
\text { significantly associated with residents' } \\
\text { perceptions". (Piedmont region, North } \\
\text { Carolina, USA) }\end{array}$ \\
\hline $\begin{array}{l}\text { Eustice, C., } \\
\text { McCole, D., } \\
\text { \& Rutty, M. }\end{array}$ & 2019 & $\begin{array}{l}\text { The impact of different } \\
\text { product messages on wine } \\
\text { tourists' willingness to } \\
\text { pay: A non-hypothetical } \\
\text { experiment }\end{array}$ & $\begin{array}{l}72 \\
242-248\end{array}$ & $\begin{array}{l}\text { The authors conclude that the impact } \\
\text { on WTP differs depending on the } \\
\text { sharing of the promotional message } \\
\text { (messages with sensory information } \\
\text { - no impact, messages about awards } \\
\text { - the most influential, messages } \\
\text { about local production - a moderate } \\
\text { increase). }\end{array}$ \\
\hline
\end{tabular}

Source: The authors' research; Reviewed papers: (Telfer, D. J., 2001), (Charters, S., \& AliKnight, J., 2002), (Bruwer, J., 2003), (Hall, C. M., 2005), (Getz, D., \& Brown, G., 2006), (Sparks, B., 2007), (Galloway, G., Mitchell, R., Getz, D., Crouch, G., \& Ong, B., 2008), (Gross, M. J., \& Brown, G., 2008), (March, R., \& Wilkinson, I., 2009), (Mason, M. C., \& Paggiaro, A., 2012), (Quintal, V. A., Thomas, B., \& Phau, I., 2015), (Gomez, M., Lopez, C., \& Molina, A., 2015), (Byrd, E. T., Canziani, B., Hsieh, Y. C. J., Debbage, K., \& Sonmez, S., 2016), (Xu, S., Barbieri, C., Anderson, D., Leung, Y. F., \& Rozier-Rich, S., 2016), (Eustice, C., McCole, D., \& Rutty, M., 2019) 
The review of the papers on wine and wine tourism in the Annals of Tourism Research is offered in the table below (Table 4.).

Table 4. The review of the papers on wine and wine tourism in Annals of Tourism Research

\begin{tabular}{|c|c|c|c|c|}
\hline Authors & Year & Title of the paper & $\begin{array}{l}\text { Volume } \\
\text { (Issue), } \\
\text { Pages } \\
\end{array}$ & Comment/Description \\
\hline Moore, R. S. & 1995 & $\begin{array}{l}\text { Gender and alcohol } \\
\text { use in a Greek } \\
\text { tourist town }\end{array}$ & $\begin{array}{l}22(2), \\
300-313\end{array}$ & $\begin{array}{l}\text { The results highlight "the importance of } \\
\text { gender in the social availability of alcohol". } \\
\text { (Greece) }\end{array}$ \\
\hline $\begin{array}{l}\text { White, C. J., } \\
\text { \& Thompson, } \\
\text { M. }\end{array}$ & 2009 & $\begin{array}{l}\text { Self determination } \\
\text { theory and the } \\
\text { wine club attribute } \\
\text { formation process }\end{array}$ & \begin{tabular}{|l}
$36(4)$, \\
$561-586$
\end{tabular} & $\begin{array}{l}\text { "Motivation orientations were found to have } \\
\text { a direct impact on preferences and with few } \\
\text { exceptions, were fully mediated by levels } \\
\text { of product and purchasing involvement in a } \\
\text { theoretically consistent manner." }\end{array}$ \\
\hline $\begin{array}{l}\text { Mitchell, R., } \\
\text { Charters, S., } \\
\text { \& Albrecht, } \\
\text { J. N. }\end{array}$ & 2012 & $\begin{array}{l}\text { Cultural systems } \\
\text { and the wine } \\
\text { tourism product }\end{array}$ & $\begin{array}{l}39(1), \\
311-335\end{array}$ & $\begin{array}{l}\text { The authors seek to introduce the application } \\
\text { of Cultural Systems in the field of wine } \\
\text { tourism by exploring the relationship of } \\
\text { rural Cultural Systems in the wine regions } \\
\text { of Champagne (France) and Margaret River } \\
\text { (Western Australia). }\end{array}$ \\
\hline $\begin{array}{l}\text { Saayman, M., } \\
\text { Krugell, W. F., } \\
\text { \& Saayman, } \\
\text { A. }\end{array}$ & 2016 & $\begin{array}{l}\text { Willingness to pay: } \\
\text { Who are the cheap } \\
\text { talkers? }\end{array}$ & $\begin{array}{l}56, \\
96-111\end{array}$ & $\begin{array}{l}\text { The authors came up with a result that } \\
\text { confirmed that "the decision to contribute } \\
\text { depends on behavioral and motivational } \\
\text { factors, while the amount is income- } \\
\text { dependent". }\end{array}$ \\
\hline Rabbiosi, C. & 2016 & $\begin{array}{l}\text { Place branding } \\
\text { performances in } \\
\text { tourist local food } \\
\text { shops }\end{array}$ & \begin{tabular}{|l}
60 \\
$154-168$
\end{tabular} & $\begin{array}{l}\text { "The study contributes to the literature } \\
\text { on tourism by proposing the concept of } \\
\text { performative place branding, enabling a } \\
\text { more creative, hybrid, and open-ended } \\
\text { consideration of the relationship between } \\
\text { tourist places and place branding." (food \& } \\
\text { wine shops - Verucchio, Italy) }\end{array}$ \\
\hline
\end{tabular}

Source: The authors' research; Reviewed papers: (Moore, R. S., 1995), (White, C. J., \& Thompson, M., 2009), (Mitchell, R., Charters, S., \& Albrecht, J. N., 2012), (Saayman, M., Krugell, W. F., \& Saayman, A., 2016), (Rabbiosi, C., 2016)

The review of the papers on wine and wine tourism in the Current Issues in Tourism is offered in the table below (Table 5.). 
Table 5. The review of the papers on wine and wine tourism in Current Issues in Tourism

\begin{tabular}{|c|c|c|c|c|}
\hline Authors & Year & Title of the paper & $\begin{array}{l}\text { Volume } \\
\text { (Issue), } \\
\text { Pages } \\
\end{array}$ & Comment/Description \\
\hline $\begin{array}{l}\text { Shanka, T. \& } \\
\text { Taylor, R. }\end{array}$ & 2004 & $\begin{array}{l}\text { Discriminating } \\
\text { Factors of First-time } \\
\text { and Repeat Visitors } \\
\text { to Wine Festivals }\end{array}$ & $\begin{array}{l}7(2), \\
134-145\end{array}$ & $\begin{array}{l}\text { "The two festival attributes with } \\
\text { discriminating abilities between the first- } \\
\text { time visitors and repeat visitors were } \\
\text { parking and services, while the four visitor } \\
\text { characteristics that showed discriminating } \\
\text { effects were age, place of residence, group } \\
\text { composition, and information sources } \\
\text { utilised." }\end{array}$ \\
\hline $\begin{array}{l}\text { Ignatov, E. \& } \\
\text { Smith, S. }\end{array}$ & 2006 & $\begin{array}{l}\text { Segmenting } \\
\text { Canadian Culinary } \\
\text { Tourists }\end{array}$ & $\begin{array}{l}9(3), \\
235-255\end{array}$ & $\begin{array}{l}\text { The wine segment is the least present (4\%), } \\
\text { while the food and wine segment is slightly } \\
\text { more present }(7 \%) \text {. Wine-only visitors } \\
\text { are balanced on gender, average age } \\
\text { and education and have higher incomes. } \\
\text { (Canada) }\end{array}$ \\
\hline $\begin{array}{l}\text { Stavrinoudis, T. } \\
\text { A., Tsartas, P., } \\
\text { \& Chatzidakis, } \\
\text { G. }\end{array}$ & 2012 & $\begin{array}{l}\text { Study of the major } \\
\text { supply factors and } \\
\text { business choices } \\
\text { affecting the growth } \\
\text { rate of wine tourism } \\
\text { in Greece } \\
\end{array}$ & $\begin{array}{l}15(7), \\
627-647\end{array}$ & $\begin{array}{l}\text { The authors analyze the development of } \\
\text { wine tourism in Greece, characteristics, key } \\
\text { elements for further development. }\end{array}$ \\
\hline $\begin{array}{l}\text { Duarte Alonso, } \\
\text { A., Bressan, A., } \\
\text { O'Shea, M. \& } \\
\text { Krajsic, V. }\end{array}$ & 2014 & $\begin{array}{l}\text { Educating } \\
\text { winery visitors } \\
\text { and consumers: } \\
\text { an international } \\
\text { perspective }\end{array}$ & $\begin{array}{l}17(6), \\
539-556\end{array}$ & $\begin{array}{l}\text { The paper presents an "international } \\
\text { perspective on wineries' educational } \\
\text { initiatives", with the most common } \\
\text { approaches to educating visitors/consumers } \\
\text { are: "guided tours, product tastings and } \\
\text { showcasing production processes" are the } \\
\text { most common approaches to educating } \\
\text { their visitors and wine consumers. }\end{array}$ \\
\hline $\begin{array}{l}\text { Popp, L. \& } \\
\text { McCole, D. }\end{array}$ & 2016 & $\begin{array}{l}\text { Understanding } \\
\text { tourists' itineraries } \\
\text { in emerging rural } \\
\text { tourism regions: } \\
\text { the application } \\
\text { of paper-based } \\
\text { itinerary mapping } \\
\text { methodology to a } \\
\text { wine tourism region } \\
\text { in Michigan } \\
\end{array}$ & $\begin{array}{l}19(10) \\
988- \\
1004\end{array}$ & $\begin{array}{l}\text { "Wine tourism is particularly well-suited } \\
\text { for itinerary mapping". The authors apply } \\
\text { paper-based itinerary mapping. (Michigan, } \\
\text { USA) }\end{array}$ \\
\hline $\begin{array}{l}\text { Bruwer, J., } \\
\text { Pratt, M. A., } \\
\text { Saliba, A. \& } \\
\text { Hirche, M. }\end{array}$ & 2017 & $\begin{array}{l}\text { Regional destination } \\
\text { image perception } \\
\text { of tourists within a } \\
\text { winescape context }\end{array}$ & $\begin{array}{l}20(2), \\
157-177\end{array}$ & $\begin{array}{l}\text { The authors found that the most important } \\
\text { dimension of the wine landscape was } \\
\text { "natural beauty / geographical setting", } \\
\text { and that the dynamics of visits (first and } \\
\text { repeated) had an impact on visitor behavior } \\
\text { and perception. }\end{array}$ \\
\hline
\end{tabular}




\begin{tabular}{|l|l|l|l|l|}
\hline Authors & Year & Title of the paper & $\begin{array}{l}\text { Volume } \\
\text { (Issue), } \\
\text { Pages }\end{array}$ & Comment/Description \\
\hline $\begin{array}{l}\text { Lee, S., } \\
\text { Bruwer, J., \& } \\
\text { Song, H. }\end{array}$ & 2017 & $\begin{array}{l}\text { Experiential and } \\
\text { involvement effects } \\
\text { on the Korean wine } \\
\text { tourist's decision- } \\
\text { making process }\end{array}$ & $\begin{array}{l}\text { 20(12), } \\
1215- \\
1231\end{array}$ & $\begin{array}{l}\text { Two constructs that relate to wine tourism } \\
\text { and form relationships with attitude are } \\
\text { a) experience of a wine tour, and b) wine } \\
\text { tourism involvement. (Korea) }\end{array}$ \\
\hline $\begin{array}{l}\text { Gómez, M., } \\
\text { Pratt, M. A., \& } \\
\text { Molina, A. }\end{array}$ & 2018 & $\begin{array}{l}\text { Wine tourism } \\
\text { research: a } \\
\text { systematic review } \\
\text { of 20 vintages from } \\
1995 \text { to 2014 }\end{array}$ & $1-39$ & $\begin{array}{l}\text { The authors review 176 wine tourism } \\
\text { papers published between 1995 and 2014, } \\
\text { and also introduce "Regional development" } \\
\text { and "the experiential wine tourist" as an } \\
\text { extension of the wine tourism research } \\
\text { framework. }\end{array}$ \\
\hline $\begin{array}{l}\text { Hassanli, N. \& } \\
\text { Ashwell, J. }\end{array}$ & 2018 & $\begin{array}{l}\text { "The main drivers in implementing } \\
\text { of small } \\
\text { accommodations to } \\
\text { a sustainable tourism } \\
\text { industry }\end{array}$ & $\begin{array}{l}\text { sustainability have been identified as } \\
\text { cost reduction competitiveness, social } \\
\text { legitimization and lifestyle values," while } \\
\text { "key challenges include personal, financial } \\
\text { and operational". (McLaren Vale, South } \\
\text { Australia) }\end{array}$ \\
\hline
\end{tabular}

Source: The authors' research; Reviewed papers: (Shanka, T. \& Taylor, R., 2004), (Ignatov, E. \& Smith, S., 2006), (Stavrinoudis, T. A., Tsartas, P., \& Chatzidakis, G., 2012), (Duarte Alonso, A., Bressan, A., O’Shea, M. \& Krajsic, V., 2014), (Popp, L. \& McCole, D., 2016), (Bruwer, J., Pratt, M. A., Saliba, A. \& Hirche, M., 2017), (Lee, S., Bruwer, J., \& Song, H., 2017), (Gómez, M., Pratt, M. A., \& Molina, A., 2018), (Hassanli, N. \& Ashwell, J., 2018)

The review of the papers on wine and wine tourism in the Journal of Sustainable Tourism is offered in the table below (Table 6.).

Table 6. The review of the papers on wine and wine tourism in Journal of Sustainable Tourism

\begin{tabular}{|l|l|l|l|l|}
\hline Authors & Year & Title of the paper & $\begin{array}{l}\text { Volume } \\
\text { (Issue), } \\
\text { Pages }\end{array}$ & Comment/Description \\
\hline $\begin{array}{l}\text { Poitras, L. \& Donald, } \\
\text { G. }\end{array}$ & 2006 & $\begin{array}{l}\text { Sustainable Wine } \\
\text { Tourism: The } \\
\text { Host Community } \\
\text { Perspective }\end{array}$ & $\begin{array}{l}\text { 14(5), } \\
425-448\end{array}$ & $\begin{array}{l}\text { The authors explore the meaning and } \\
\text { elements of sustainable wine tourism } \\
\text { from a perspective of the community. } \\
\text { (Town of Oliver, British Columbia, } \\
\text { Canada) }\end{array}$ \\
\hline $\begin{array}{l}\text { Alonso, A. D. \& Liu, } \\
\text { Y. }\end{array}$ & $\begin{array}{l}\text { Old wine region, } \\
\text { new concept } \\
\text { and sustainable } \\
\text { development: } \\
\text { winery } \\
\text { entrepreneurs' } \\
\text { perceived benefits } \\
\text { from wine tourism } \\
\text { on Spain's Canary } \\
\text { Islands }\end{array}$ & $\begin{array}{l}\text { 20(7), } \\
991-1009\end{array}$ & $\begin{array}{l}\text { The benefits for most winery } \\
\text { entrepreneurs (59\%) are only marginal } \\
\text { or none at all, while "little government } \\
\text { support, lack of organization within } \\
\text { the wine sector and limited resources" } \\
\text { are present as problems, so "research, } \\
\text { partnership creation and marketing" } \\
\text { are needed to achieve sustainability. } \\
\text { (Spain's Canary Islands) }\end{array}$ \\
\hline
\end{tabular}

Source: The authors' research; Reviewed papers: (Poitras, L. \& Donald, G., 2006), (Alonso, A. D. \& Liu, Y., 2012) 
The review of the papers on wine and wine tourism in the Journal of Hospitality \& Tourism Research is offered in the table below (Table 7.).

Table 7. The review of the papers on wine and wine tourism in Journal of Hospitality \& Tourism Research

\begin{tabular}{|c|c|c|c|c|}
\hline Authors & Year & Title of the paper & $\begin{array}{l}\text { Volume } \\
\text { (Issue), } \\
\text { Pages }\end{array}$ & Comment/Description \\
\hline Fox, M. & 1989 & $\begin{array}{l}\text { Quality Assurance and } \\
\text { Sensory Evaluation in } \\
\text { Foodservice-a New } \\
\text { Course for Foodservice } \\
\text { Managers }\end{array}$ & $\begin{array}{l}13(3) \\
554-554\end{array}$ & $\begin{array}{l}\text { The author lists "beverage taste } \\
\text { testing panel procedures and leave a } \\
\text { good taste for the course in students' } \\
\text { mouths as wine tasting is conducted". }\end{array}$ \\
\hline Dodd, T. H. & 1996 & $\begin{array}{l}\text { Factors that Influence the } \\
\text { Adoption and Diffusion } \\
\text { of New Wine Products }\end{array}$ & \begin{tabular}{|l}
$20(3)$ \\
$123-136$
\end{tabular} & $\begin{array}{l}\text { "The results of the survey of wine } \\
\text { consumers found that although } \\
\text { there were similarities in the socio- } \\
\text { demographic variables of innovators } \\
\text { and noninnovators of a new wine } \\
\text { product, the two groups differed } \\
\text { with respect to their behavioral } \\
\text { characteristics, and the sources from } \\
\text { which they collected their information } \\
\text { concerning wine." }\end{array}$ \\
\hline $\begin{array}{l}\text { Rutherford, D. } \\
\text { G., Perkins, } \\
\text { A. W., \& } \\
\text { Spangenberg, } \\
\text { E. R. }\end{array}$ & 2000 & $\begin{array}{l}\text { Trade Dress and } \\
\text { Consumer Perception of } \\
\text { Product Similarity }\end{array}$ & $\begin{array}{l}24(2) \\
163-179\end{array}$ & $\begin{array}{l}\text { "The authors suggest that brand } \\
\text { loyalty is less likely and switching } \\
\text { behavior may become common in a } \\
\text { market that includes such competitive } \\
\text { behavior." (product is wine) }\end{array}$ \\
\hline $\begin{array}{l}\text { Dodd, T. H., } \\
\text { Laverie, D. A., } \\
\text { Wilcox, J. F., \& } \\
\text { Duhan, D. F. }\end{array}$ & 2005 & $\begin{array}{l}\text { Differential Effects of } \\
\text { Experience, Subjective } \\
\text { Knowledge, and } \\
\text { Objective Knowledge on } \\
\text { Sources of Information } \\
\text { used in Consumer Wine } \\
\text { Purchasing } \\
\end{array}$ & $\begin{array}{l}29(1) \\
3-19\end{array}$ & $\begin{array}{l}\text { "Results indicate that usage } \\
\text { experience forms the basis for } \\
\text { subjective and objective knowledge". } \\
\text { (Texas, USA) }\end{array}$ \\
\hline $\begin{array}{l}\text { Lee, K., Zhao, } \\
\text { J., \& Ko, J.-Y. }\end{array}$ & 2005 & $\begin{array}{l}\text { Exploring the Korean } \\
\text { Wine Market }\end{array}$ & $\begin{array}{l}29(1) \\
20-41\end{array}$ & $\begin{array}{l}\text { "The study found Korean wine } \\
\text { consumers had interesting preferences } \\
\text { and that there were some significant } \\
\text { differences between these preferences } \\
\text { and demographic characteristics } \\
\text { among the Korean respondents." } \\
\text { (Korea) } \\
\end{array}$ \\
\hline $\begin{array}{l}\text { Charters, S., \& } \\
\text { Menival, D. }\end{array}$ & 2011 & $\begin{array}{l}\text { Wine Tourism in } \\
\text { Champagne }\end{array}$ & $\begin{array}{l}35(1) \\
102-118\end{array}$ & $\begin{array}{l}\text { The authors found that: a) producers } \\
\text { have three approaches to wine } \\
\text { tourism, b) "producers can have } \\
\text { a small idea of what tourists find } \\
\text { acceptable", c) smaller producers can } \\
\text { add value to their product (tourists } \\
\text { pay more than local customers). } \\
\text { (Champagne, France) }\end{array}$ \\
\hline
\end{tabular}




\begin{tabular}{|c|c|c|c|c|}
\hline Authors & Year & Title of the paper & \begin{tabular}{|l|} 
Volume \\
(Issue), \\
Pages \\
\end{tabular} & Comment/Description \\
\hline $\begin{array}{l}\text { Alonso, A. D., } \\
\& \text { Liu, Y. }\end{array}$ & 2012 & $\begin{array}{l}\text { Visitor Centers, } \\
\text { Collaboration, and the } \\
\text { Role of Local Food and } \\
\text { Beverage as Regional } \\
\text { Tourism Development } \\
\text { Tools: The Case of the } \\
\text { Blackwood River Valley } \\
\text { in Western Australia }\end{array}$ & $\begin{array}{l}36(4), \\
517-536\end{array}$ & $\begin{array}{l}\text { The authors found that "that not } \\
\text { enough emphasis is placed on } \\
\text { promoting food-, wine-, and farm- } \\
\text { related tourism themes". (Blackwood } \\
\text { River Valley, Western Australia) }\end{array}$ \\
\hline $\begin{array}{l}\text { Carlsen, J., \& } \\
\text { Boksberger, P. }\end{array}$ & 2015 & $\begin{array}{l}\text { Enhancing Consumer } \\
\text { Value in Wine Tourism }\end{array}$ & $\begin{array}{l}39(1), \\
132-144\end{array}$ & $\begin{array}{l}\text { "Studies are both qualitative and } \\
\text { quantitative, and both approaches } \\
\text { provided findings that are merged into } \\
\text { a single matrix of key attribute types." }\end{array}$ \\
\hline $\begin{array}{l}\text { Cho, M., Bonn, } \\
\text { M. A., \& } \\
\text { Brymer, R. A. }\end{array}$ & 2017 & $\begin{array}{l}\text { A Constraint-Based } \\
\text { Approach to Wine } \\
\text { Tourism Market } \\
\text { Segmentation }\end{array}$ & $\begin{array}{l}41(4) \\
415-444\end{array}$ & $\begin{array}{l}\text { The authors created five homogeneous } \\
\text { subgroups ("Highly Constrained, } \\
\text { Cost \& Time Conscious, Family } \\
\text { Togetherness, Unmotivated, and } \\
\text { Minimally Constrained") applying } \\
\text { constraints scales that are tailored to } \\
\text { wine tourism. }\end{array}$ \\
\hline $\begin{array}{l}\text { Ye, B. H., } \\
\text { Zhang, H. Q., } \\
\text { \& Yuan, J. }\end{array}$ & 2017 & $\begin{array}{l}\text { Intentions to Participate } \\
\text { in Wine Tourism in } \\
\text { an Emerging Market: } \\
\text { Theorization and } \\
\text { Implications }\end{array}$ & $\begin{array}{l}41(8) \\
1007- \\
1031\end{array}$ & $\begin{array}{l}\text { The authors found that: a) "subjective } \\
\text { norm influences visit intentions } \\
\text { through the mediating role of travel } \\
\text { motivation and so to attitudes toward } \\
\text { domestic wine when mediated by } \\
\text { wine-specific travel motivation", b) } \\
\text { "past experiences positively affected } \\
\text { visit intentions", c ) "A lack of wine } \\
\text { knowledge and low confidence } \\
\text { in domestic wine inhibited visit } \\
\text { intentions". }\end{array}$ \\
\hline $\begin{array}{l}\text { Thomas, B., } \\
\text { Quintal, V. A., } \\
\text { \& Phau, I. }\end{array}$ & 2018 & $\begin{array}{l}\text { Wine Tourist } \\
\text { Engagement With } \\
\text { the Winescape: Scale } \\
\text { Development and } \\
\text { Validation }\end{array}$ & $\begin{array}{l}42(5), \\
793-828\end{array}$ & $\begin{array}{l}\text { The authors found that "the resultant } \\
20 \text {-item winescape scale" was } \\
\text { composed of } 7 \text { attributes (setting, } \\
\text { atmospherics, wine quality, wine } \\
\text { value, complementary product, } \\
\text { signage, service staff) reliable and } \\
\text { valid. }\end{array}$ \\
\hline
\end{tabular}

Source: The authors' research; Reviewed papers: (Fox, M., 1989), (Dodd, T. H., 1996), (Rutherford, D. G., Perkins, A. W., \& Spangenberg, E. R., 2000), (Dodd, T. H., Laverie, D. A., Wilcox, J. F., \& Duhan, D. F., 2005), (Lee, K., Zhao, J., \& Ko, J.-Y., 2005), (Charters, S., \& Menival, D., 2011), (Alonso, A. D., \& Liu, Y., 2012), (Carlsen, J., \& Boksberger, P., 2015), (Cho, M., Bonn, M. A., \& Brymer, R. A., 2017), (Ye, B. H., Zhang, H. Q., \& Yuan, J., 2017), (Thomas, B., Quintal, V. A., \& Phau, I., 2018)

The review of the papers on wine and wine tourism in the International Journal of Tourism Research is offered in the table below (Table 8.). 
Table 8. The review of the papers on wine and wine tourism in International Journal of Tourism Research

\begin{tabular}{|c|c|c|c|c|}
\hline Authors & Year & Title of the paper & \begin{tabular}{|l|} 
Volume \\
(Issue), \\
Pages \\
\end{tabular} & Comment/Description \\
\hline $\begin{array}{l}\text { Hjalager, } \\
\text { A. M., \& } \\
\text { Corigliano, } \\
\text { M. A. }\end{array}$ & 2000 & $\begin{array}{l}\text { Food for tourists- } \\
\text { determinants of an image }\end{array}$ & \begin{tabular}{|l}
$2(4)$ \\
$281-293$
\end{tabular} & $\begin{array}{l}\text { The authors point out that the } \\
\text { combination of food and tourism } \\
\text { is increasingly pronounced, which } \\
\text { can be seen, among other things, } \\
\text { in wine tours. A comparison was } \\
\text { made between Denmark and Italy } \\
\text { regarding the development and } \\
\text { standards of food for tourists, which } \\
\text { "are not determined uniformly } \\
\text { by tourism policies, but more } \\
\text { significantly by national economic, } \\
\text { agricultural and food policies". }\end{array}$ \\
\hline $\begin{array}{l}\text { Jaffe, E., \& } \\
\text { Pasternak, H. }\end{array}$ & 2004 & $\begin{array}{l}\text { Developing wine trails as a } \\
\text { tourist attraction in Israel }\end{array}$ & $\begin{array}{l}6(4) \\
237-249\end{array}$ & $\begin{array}{l}\text { The authors found that "there was } \\
\text { a high degree of understanding of } \\
\text { tourist needs among the winery } \\
\text { operators". (Israel) }\end{array}$ \\
\hline $\begin{array}{l}\text { Yuan, J., } \\
\text { Morrison, A. } \\
\text { M., Cai, L. } \\
\text { A., \& Linton, } \\
\text { S. }\end{array}$ & 2008 & $\begin{array}{l}\text { A model of wine tourist } \\
\text { behaviour: a festival } \\
\text { approach }\end{array}$ & $\begin{array}{l}10(3) \\
207-219\end{array}$ & $\begin{array}{l}\text { "The study constructs a temporal } \\
\text { model of wine tourist behavior" } \\
\text { highlighting two new dimensions } \\
\text { "by proposing that satisfaction and } \\
\text { perceived value had an impact on } \\
\text { attendees' intentions (i) to visit a } \\
\text { local winery and (ii) to buy local } \\
\text { wine products". }\end{array}$ \\
\hline $\begin{array}{l}\text { Scherrer, P., } \\
\text { Alonso, A., \& } \\
\text { Sheridan, L. }\end{array}$ & 2009 & $\begin{array}{l}\text { Expanding the destination } \\
\text { image: Wine tourism in the } \\
\text { Canary Islands }\end{array}$ & $\begin{array}{l}11(5) \\
451-463\end{array}$ & $\begin{array}{l}\text { The authors point out that } \\
\text { "challenges to overcome in the } \\
\text { development of a successful } \\
\text { sustainable local wine tourism } \\
\text { industry include the need for } \\
\text { expansion of the destination image } \\
\text { to reflect the region's wine } \square \text { making } \\
\text { history and scenic qualities; a shift } \\
\text { towards independent high } \square \text { yield } \\
\text { travellers; and reintroducing } \\
\text { local produce in the mass tourism } \\
\text { product." (Canary Islands) }\end{array}$ \\
\hline $\begin{array}{l}\text { Gómez, M., } \\
\text { \& Molina, A. }\end{array}$ & 2012 & $\begin{array}{l}\text { Wine tourism in Spain: } \\
\text { denomination of origin } \\
\text { effects on brand equity }\end{array}$ & $\begin{array}{l}14(4), \\
353-368\end{array}$ & $\begin{array}{l}\text { The authors strive for "the } \\
\text { development of a model to study } \\
\text { the influence of the denomination } \\
\text { of origin brand image, as a regional } \\
\text { brand, and destination image on } \\
\text { wine tourism destination brand } \\
\text { equity". (Spain) }\end{array}$ \\
\hline
\end{tabular}




\begin{tabular}{|c|c|c|c|c|}
\hline Authors & Year & Title of the paper & $\begin{array}{l}\text { Volume } \\
\text { (Issue), } \\
\text { Pages } \\
\end{array}$ & Comment/Description \\
\hline Bruwer, J. & 2014 & $\begin{array}{l}\text { Service quality perception } \\
\text { and satisfaction: Buying } \\
\text { behaviour prediction in an } \\
\text { Australian Festivalscape }\end{array}$ & $\begin{array}{l}16(1), \\
76-86\end{array}$ & $\begin{array}{l}\text { The authors provide a new look at } \\
\text { festivalscape through the dynamics } \\
\text { of first-time visitors and repeat } \\
\text { visitors. Repeat visitors are the most } \\
\text { productive group to visit for wine } \\
\text { shopping, while first-time visitors } \\
\text { are "are more short } \square \text { term oriented } \\
\text { in their planning when making the } \\
\text { final decision to attend the event". } \\
\text { (Australia) }\end{array}$ \\
\hline $\begin{array}{l}\text { Alonso, A. } \\
\text { D., Bressan, } \\
\text { A., O’Shea, } \\
\text { M., \& } \\
\text { Krajsic, V. }\end{array}$ & 2015 & $\begin{array}{l}\text { Perceived benefits and } \\
\text { challenges to wine } \\
\text { tourism involvement: An } \\
\text { international perspective }\end{array}$ & $\begin{array}{l}17(1), \\
66-81\end{array}$ & $\begin{array}{l}\text { According to the authors, the main } \\
\text { benefits of wineries from wine } \\
\text { tourism relate to "the promotion } \\
\text { of the winery's wines, distantly } \\
\text { followed by the potential to } \\
\text { significantly increase wine sales". } \\
\text { (wineries predominantly located in } \\
\text { Italy and Spain) }\end{array}$ \\
\hline $\begin{array}{l}\text { Jones, M. F., } \\
\text { Singh, N., \& } \\
\text { Hsiung, Y. }\end{array}$ & 2015 & \begin{tabular}{|l|} 
Determining the critical \\
success factors of the wine \\
tourism region of Napa \\
from a supply perspective \\
\end{tabular} & $\begin{array}{l}17(3), \\
261-271\end{array}$ & $\begin{array}{l}\text { "Findings reveal an aligned } \\
\text { marketing effort and strategic } \\
\text { partnerships among suppliers of } \\
\text { Napa wine tourism." } \\
\end{array}$ \\
\hline $\begin{array}{l}\text { Alamanos, } \\
\text { E., Kuznesof, } \\
\text { S., \& Ritson, } \\
\text { C. }\end{array}$ & 2016 & $\begin{array}{l}\text { The influence of holidays } \\
\text { on wine purchasing } \\
\text { behaviour: marketing and } \\
\text { tourism insights based on } \\
\text { a holiday experience in } \\
\text { Greece }\end{array}$ & $\begin{array}{l}18(3), \\
228-235\end{array}$ & $\begin{array}{l}\text { "The effect is greater on highly } \\
\text { involved wine consumers and } \\
\text { depends on their knowledge of } \\
\text { wines from the country, specifically } \\
\text { grape varieties, wine producing } \\
\text { areas and territorial certifications". } \\
\text { (UK wine consumers who have } \\
\text { holidayed in Greece) }\end{array}$ \\
\hline $\begin{array}{l}\text { Bruwer, J., } \\
\text { Prayag, G., \& } \\
\text { Disegna, M. }\end{array}$ & 2018 & \begin{tabular}{|l|} 
Why wine tourists visit \\
cellar doors: Segmenting \\
motivation and destination \\
image \\
\end{tabular} & $\begin{array}{l}20(3), \\
355-366\end{array}$ & $\begin{array}{l}\text { The authors found "significant } \\
\text { relationships were found between } \\
\text { the motivation and destination } \\
\text { image clusters". }\end{array}$ \\
\hline $\begin{array}{l}\text { Gu, Q., \& } \\
\text { Huang, S. }\end{array}$ & 2019 & $\begin{array}{l}\text { Profiling Chinese wine } \\
\text { tourists by wine tourism } \\
\text { constraints: A comparison } \\
\text { of Chinese Australians and } \\
\text { long } \square \text { haul Chinese tourists } \\
\text { in Australia }\end{array}$ & $\begin{array}{l}21(2), \\
206-220\end{array}$ & $\begin{array}{l}\text { Four wine tourism constraint factors } \\
\text { and three negotiation factors were } \\
\text { identified. }\end{array}$ \\
\hline
\end{tabular}

Source: The authors' research; Reviewed papers: (Hjalager, A. M., \& Corigliano, M. A., 2000), (Jaffe, E., \& Pasternak, H., 2004), (Yuan, J., Morrison, A. M., Cai, L. A., \& Linton, S., 2008), (Scherrer, P., Alonso, A., \& Sheridan, L., 2009), (Gómez, M., \& Molina, A., 2012), (Bruwer, J., 2014), (Alonso, A. D., Bressan, A., O’Shea, M., \& Krajsic, V., 2015), (Jones, M. F., Singh, N., \& Hsiung, Y., 2015), (Alamanos, E., Kuznesof, S., \& Ritson, C., 2016), (Bruwer, J., Prayag, G., \& Disegna, M., 2018), (Gu, Q., \& Huang, S., 2019) 
The review of the papers on wine and wine tourism in the Tourism Geographies is offered in the table below (Table 9.).

Table 9. The review of the papers on wine and wine tourism in Tourism Geographies

\begin{tabular}{|l|l|l|l|l|}
\hline Authors & Year & $\begin{array}{l}\text { Title of the } \\
\text { paper }\end{array}$ & $\begin{array}{l}\text { Volume (Issue), } \\
\text { Pages }\end{array}$ & Comment/Description \\
\hline $\begin{array}{l}\text { Carmichael, } \\
\text { B. }\end{array}$ & 2005 & $\begin{array}{l}\text { Understanding } \\
\text { the wine } \\
\text { tourism } \\
\text { experience for } \\
\text { winery visitors } \\
\text { in the Niagara } \\
\text { region, Ontario, } \\
\text { Canada }\end{array}$ & $\begin{array}{l}7(2), \\
185-204\end{array}$ & $\begin{array}{l}\text { The author initiates the consideration } \\
\text { of "the symbiosis between wineries } \\
\text { and tourists and the quality of the wine } \\
\text { tourism experience". (Niagara region, } \\
\text { Ontario, Canada) }\end{array}$ \\
\hline $\begin{array}{l}\text { Ferreira, S. } \\
\text { L., \& Hunter, } \\
\text { C. A. }\end{array}$ & 2017 & $\begin{array}{l}\text { Wine tourism } \\
\text { development in } \\
\text { South Africa: } \\
\text { a geographical } \\
\text { analysis }\end{array}$ & $\begin{array}{l}\text { 19(5), } \\
676-698\end{array}$ & $\begin{array}{l}\text { The authors found that there was a } \\
\text { "hierarchical differentiation between the } \\
\text { wineries of the more established wine } \\
\text { tourism regions has emerged", and that } \\
\text { the development of wine tourism was } \\
\text { responsible for the transformation of rural } \\
\text { landscapes (especially in the regions with } \\
\text { the most developed wine routes). (South } \\
\text { Africa) }\end{array}$ \\
\hline
\end{tabular}

Source: The authors' research; Reviewed papers: (Carmichael, B., 2005), (Ferreira, S. L., \& Hunter, C. A., 2017)

The review of the papers on wine and wine tourism in the Journal of Travel \& Tourism Marketing is offered in the table below (Table 10.).

Table 10. The review of the papers on wine and wine tourism in Journal of Travel \& Tourism Marketing

\begin{tabular}{|l|l|l|l|l|}
\hline Authors & Year & Title of the paper & $\begin{array}{l}\text { Volume } \\
\text { (Issue), } \\
\text { Pages }\end{array}$ & Comment/Description \\
\hline $\begin{array}{l}\text { Williams, P. W., } \\
\text { \& Dossa, K. B. }\end{array}$ & 2003 & $\begin{array}{l}\text { Non-resident wine } \\
\text { tourist markets: } \\
\text { Implications for British } \\
\text { Columbia's emerging } \\
\text { wine tourism industry }\end{array}$ & $\begin{array}{l}14(3-4), \\
1-34\end{array}$ & $\begin{array}{l}\text { The authors use "an importance- } \\
\text { performance analysis framework } \\
\text { to determine the key areas for } \\
\text { management activity that need } \\
\text { to be addressed in order to meet } \\
\text { the travel product needs" of each } \\
\text { segments. (British Columbia) }\end{array}$ \\
\hline $\begin{array}{l}\text { Westering, J. V., } \\
\text { \& Niel, E. }\end{array}$ & 2003 & $\begin{array}{l}\text { The organization of } \\
\text { wine tourism in France: } \\
\text { The involvement of the } \\
\text { French public sector }\end{array}$ & $\begin{array}{l}\text { The authors concluded that the } \\
\text { public sector is made up of many } \\
\text { bodies at different levels, and that } \\
\text { there are difficulties in working } \\
\text { together towards collective goals. } \\
\text { Also, "communications between } \\
\text { involved parties is often slow due } \\
\text { to differing political loyalties". } \\
\text { (France) }\end{array}$ \\
\hline
\end{tabular}




\begin{tabular}{|c|c|c|c|c|}
\hline Authors & Year & Title of the paper & \begin{tabular}{|l|} 
Volume \\
(Issue), \\
Pages \\
\end{tabular} & Comment/Description \\
\hline $\begin{array}{l}\text { Hashimoto, A., \& } \\
\text { Telfer, D. J. }\end{array}$ & 2003 & $\begin{array}{l}\text { Positioning an } \\
\text { emerging wine route } \\
\text { in the Niagara region: } \\
\text { Understanding the } \\
\text { wine tourism market } \\
\text { and its implications for } \\
\text { marketing }\end{array}$ & $\begin{array}{l}14(3-4) \\
61-76\end{array}$ & $\begin{array}{l}\text { This paper shows "the different } \\
\text { markets visiting the Niagara } \\
\text { Wine Route and suggests possible } \\
\text { implications for marketing } \\
\text { strategies for this emerging wine } \\
\text { route". (Niagara region) }\end{array}$ \\
\hline Frochot, I. & 2003 & $\begin{array}{l}\text { An analysis of regional } \\
\text { positioning and its } \\
\text { associated food images } \\
\text { in French tourism } \\
\text { regional brochures } \\
\end{array}$ & $\begin{array}{l}14(3-4) \\
77-96\end{array}$ & $\begin{array}{l}\text { The authors found that "country } \\
\text { products/dishes and raw/natural } \\
\text { products dominate food images } \\
\text { followed by wine and vineyards } \\
\text { images". (France) }\end{array}$ \\
\hline Demhardt, I. J. & 2003 & $\begin{array}{l}\text { Wine and Tourism at } \\
\text { the "Fairest Cape" } \\
\text { Post-Apartheid } \\
\text { Trends in the Western } \\
\text { Cape Province and } \\
\text { Stellenbosch (South } \\
\text { Africa) }\end{array}$ & $\begin{array}{l}14(3-4) \\
113-130\end{array}$ & $\begin{array}{l}\text { The authors analyze Stallenbosch } \\
\text { and Stallenbosch Wine Route, } \\
\text { Wine Route, and also conclude } \\
\text { that "a new trend in wine tourism } \\
\text { is highlighted by a case study } \\
\text { of the hybrid wine and tourism } \\
\text { developments at Spier Resort". } \\
\text { (South Africa) }\end{array}$ \\
\hline $\begin{array}{l}\text { Mitchell, R. D., } \\
\text { \& Hall, C. M. }\end{array}$ & 2003 & $\begin{array}{l}\text { Seasonality in New } \\
\text { Zealand winery } \\
\text { visitation: An issue of } \\
\text { demand and supply }\end{array}$ & $\begin{array}{l}14(3-4) \\
155-173\end{array}$ & $\begin{array}{l}\text { The authors analyze the } \\
\text { seasonality of visits and suggest } \\
\text { "a number of marketing strategies } \\
\text { by which some of the effects of } \\
\text { seasonality may be overcome in } \\
\text { terms of both target markets and } \\
\text { the improved management of } \\
\text { human resources". (New Zealand) }\end{array}$ \\
\hline $\begin{array}{l}\text { Brown, G. P., } \\
\text { Havitz, M. E., \& } \\
\text { Getz, D. }\end{array}$ & 2007 & $\begin{array}{l}\text { Relationship between } \\
\text { wine involvement and } \\
\text { wine-related travel }\end{array}$ & $\begin{array}{l}21(1) \\
31-46\end{array}$ & $\begin{array}{l}\text { The authors (analyzing the } \\
\text { demographically diverse } \\
\text { respondents) found that "although } \\
\text { between market demographic } \\
\text { differences were minimal, } \\
\text { consumptive behaviours related } \\
\text { to wine and wine tourism were } \\
\text { consistent and profound ( } \mathrm{p}< \\
.05) \text { ". (Canada) } \\
\end{array}$ \\
\hline $\begin{array}{l}\text { Barber, N. A., } \\
\text { Donovan, J. R., } \\
\text { \& Dodd, T. H. }\end{array}$ & 2008 & $\begin{array}{l}\text { Differences in tourism } \\
\text { marketing strategies } \\
\text { between wineries based } \\
\text { on size or location }\end{array}$ & $\begin{array}{l}25(1) \\
43-57\end{array}$ & $\begin{array}{l}\text { By examining on-site and off- } \\
\text { site marketing strategies ("based } \\
\text { upon winery size and location"), } \\
\text { the authors found that there were } \\
\text { differences in "particularly with } \\
\text { wine education at rural wineries } \\
\text { and food/wine pairing techniques } \\
\text { at larger wineries". }\end{array}$ \\
\hline
\end{tabular}




\begin{tabular}{|c|c|c|c|c|}
\hline Authors & Year & Title of the paper & \begin{tabular}{|l|} 
Volume \\
(Issue), \\
Pages
\end{tabular} & Comment/Description \\
\hline $\begin{array}{l}\text { Park, K. S., } \\
\text { Reisinger, Y., \& } \\
\text { Kang, H. J. }\end{array}$ & 2008 & $\begin{array}{l}\text { Visitors' motivation } \\
\text { for attending the South } \\
\text { Beach wine and food } \\
\text { festival, Miami Beach, } \\
\text { Florida }\end{array}$ & \begin{tabular}{|l}
$25(2)$ \\
$161-181$
\end{tabular} & $\begin{array}{l}\text { The authors found that there were } \\
7 \text { factors that motivated first-time } \\
\text { visitors to the festival, and that } \\
\text { the biggest difference (between } 5 \\
\text { segments) is present with family } \\
\text { influence. }\end{array}$ \\
\hline $\begin{array}{l}\text { Marzo } \square \text { Navarro, } \\
\text { M., \& Pedraja } \square \\
\text { Iglesias, M. }\end{array}$ & 2009 & $\begin{array}{l}\text { Profile of a wine tourist } \\
\text { and the correspondence } \\
\text { between destination } \\
\text { and preferred wine: A } \\
\text { study in Aragon, Spain }\end{array}$ & $\begin{array}{l}26(7) \\
670-687\end{array}$ & $\begin{array}{l}\text { The authors found that "the } \\
\text { profile of a wine tourist can be } \\
\text { divided into two groups", and } \\
\text { also that there was a "positive } \\
\text { correspondence between the place } \\
\text { of origin of a preferred wine and } \\
\text { the destination selected when } \\
\text { participating in wine tourism". } \\
\text { (Aragon, Spain) }\end{array}$ \\
\hline $\begin{array}{l}\text { Kolyesnikova, } \\
\text { N., \& Dodd, T. H. }\end{array}$ & 2009 & $\begin{array}{l}\text { There is no such thing } \\
\text { as a free wine tasting: } \\
\text { The effect of a tasting } \\
\text { fee on obligation to buy }\end{array}$ & $\begin{array}{l}26(8) \\
806-819\end{array}$ & $\begin{array}{l}\text { The authors found that visitors to } \\
\text { the free wine tastings (compared } \\
\text { to paying fee visitors) spent more } \\
\text { money, "felt significantly more } \\
\text { appreciative of the personnel", and } \\
\text { felt a stronger obligation to make } \\
\text { the purchase. }\end{array}$ \\
\hline $\begin{array}{l}\text { Barber, N., } \\
\text { Taylor, D. C., \& } \\
\text { Deale, C. S. }\end{array}$ & 2010 & $\begin{array}{l}\text { Wine tourism, } \\
\text { environmental } \\
\text { concerns, and purchase } \\
\text { intention }\end{array}$ & $\begin{array}{l}27(2), \\
146-165\end{array}$ & $\begin{array}{l}\text { "Wine tourists may be willing to } \\
\text { pay for environmentally friendly } \\
\text { wines with females possessing } \\
\text { stronger environmental attitudes } \\
\text { about protecting wine region } \\
\text { destinations, thus influencing } \\
\text { stronger behaviors toward } \\
\text { purchase intention." }\end{array}$ \\
\hline $\begin{array}{l}\text { Bruwer, J., \& } \\
\text { Lesschaeve, I. }\end{array}$ & 2012 & $\begin{array}{l}\text { Wine tourists' } \\
\text { destination region } \\
\text { brand image perception } \\
\text { and antecedents: } \\
\text { Conceptualization of a } \\
\text { winescape framework }\end{array}$ & $\begin{array}{l}29(7) \\
611-628\end{array}$ & $\begin{array}{l}\text { Natural beauty / setting } \\
\text { (landscape) of the region is } \\
\text { the most important dimension } \\
\text { of winescape, and the other } \\
\text { significant ones are "the service } \\
\text { staff and friendly local people, } \\
\text { overall ambience and the diversity } \\
\text { of wine estates". }\end{array}$ \\
\hline $\begin{array}{l}\text { Savinovic, A., } \\
\text { Kim, S., \& Long, } \\
\text { P. }\end{array}$ & 2012 & $\begin{array}{l}\text { Audience members' } \\
\text { motivation, satisfaction, } \\
\text { and intention to re-visit } \\
\text { an ethnic minority } \\
\text { cultural festival }\end{array}$ & $\begin{array}{l}29(7) \\
682-694\end{array}$ & $\begin{array}{l}\text { Eight major motivators for } \\
\text { attending national minority } \\
\text { cultural festivals (community } \\
\text { support; escape; knowledge/ } \\
\text { education; food, wine, and } \\
\text { entertainment; novelty; family } \\
\text { togetherness; marketing; } \\
\text { socialization). (2009 Feŝta - } \\
\text { Croatian Food and Wine Festival } \\
\text { in Adelaide, South Australia) }\end{array}$ \\
\hline
\end{tabular}




\begin{tabular}{|c|c|c|c|c|}
\hline Authors & Year & Title of the paper & \begin{tabular}{|l|} 
Volume \\
(Issue), \\
Pages
\end{tabular} & Comment/Description \\
\hline $\begin{array}{l}\text { Mikulić, J., } \\
\text { Paunović, Z., \& } \\
\text { Prebežac, D. }\end{array}$ & 2012 & $\begin{array}{l}\text { An extended } \\
\text { neural network- } \\
\text { based importance- } \\
\text { performance analysis } \\
\text { for enhancing wine fair } \\
\text { experience }\end{array}$ & $\begin{array}{l}29(8) \\
744-759\end{array}$ & $\begin{array}{l}\text { The authors used "an extended } \\
\text { neural network-based importance- } \\
\text { performance analysis (IPA) } \\
\text { that combines measures of } \\
\text { both the relevance (i.e., stated } \\
\text { importance/general importance) } \\
\text { and determinance (i.e., derived } \\
\text { importance/actual influence) of } \\
\text { fair attributes" to analyze the data. } \\
\text { (Dalmacija Wine Expo, Makarska, } \\
\text { Croatia) }\end{array}$ \\
\hline $\begin{array}{l}\text { Pratt, M. A., \& } \\
\text { Sparks, B. }\end{array}$ & 2014 & $\begin{array}{l}\text { Predicting wine tourism } \\
\text { intention: Destination } \\
\text { image and self- } \\
\text { congruity }\end{array}$ & $\begin{array}{l}31(4), \\
443-460\end{array}$ & $\begin{array}{l}\text { "Functional destination image, } \\
\text { affective destination image, and } \\
\text { self-congruity predict attitude } \\
\text { toward wine tourism, which } \\
\text { in turn predicts behavioral } \\
\text { intentions." (Australia) }\end{array}$ \\
\hline $\begin{array}{l}\text { Nella, A., \& } \\
\text { Christou, E. }\end{array}$ & 2014 & $\begin{array}{l}\text { Segmenting wine } \\
\text { tourists on the basis of } \\
\text { involvement with wine }\end{array}$ & $\begin{array}{l}31(7) \\
783-798\end{array}$ & $\begin{array}{l}\text { "Results confirm that it is } \\
\text { meaningful to segment winery } \\
\text { visitors on the basis of their } \\
\text { involvement with wine, as } \\
\text { important differences can be } \\
\text { identified". }\end{array}$ \\
\hline $\begin{array}{l}\text { Cuellar, S. S., } \\
\text { Eyler, R. C., \& } \\
\text { Fanti, R. }\end{array}$ & 2015 & $\begin{array}{l}\text { Experiential marketing } \\
\text { and long-term sales }\end{array}$ & $\begin{array}{l}32(5) \\
534-553\end{array}$ & $\begin{array}{l}\text { Wine tasting rooms are forms of } \\
\text { experiential marketing because } \\
\text { they contribute to "creating brand } \\
\text { awareness and generating greater } \\
\text { growth in off-premise retail sales". }\end{array}$ \\
\hline $\begin{array}{l}\text { Gu, Q., Qiu } \\
\text { Zhang, H., King, } \\
\text { B., \& Huang, S. }\end{array}$ & 2018 & $\begin{array}{l}\text { Wine tourism } \\
\text { involvement: a } \\
\text { segmentation of } \\
\text { Chinese tourists }\end{array}$ & $\begin{array}{l}35(5) \\
633-648\end{array}$ & $\begin{array}{l}\text { "Significant differences were } \\
\text { found for behavioral variables } \\
\text { and activity participation level", } \\
\text { "but similarity outweighed the } \\
\text { differences among demographic } \\
\text { and socio-economic variables". }\end{array}$ \\
\hline $\begin{array}{l}\text { Canovi, M., \& } \\
\text { Pucciarelli, F. }\end{array}$ & 2019 & $\begin{array}{l}\text { Social media marketing } \\
\text { in wine tourism: winery } \\
\text { owners' perceptions }\end{array}$ & $\begin{array}{l}36(6) \\
653-664\end{array}$ & $\begin{array}{l}\text { "The findings show that while } \\
\text { the majority of winery owners } \\
\text { recognise the social, economic and } \\
\text { emotional benefits of social media, } \\
\text { they are far from exploiting its full } \\
\text { potential". }\end{array}$ \\
\hline
\end{tabular}

Source: The authors' research; Reviewed papers: (Williams, P. W., \& Dossa, K. B., 2003),

(Westering, J. V., \& Niel, E., 2003), (Hashimoto, A., \& Telfer, D. J., 2003), (Frochot, I., 2003), (Demhardt, I. J., 2003), (Mitchell, R. D., \& Hall, C. M., 2003), (Brown, G. P., Havitz,

M. E., \& Getz, D., 2007), (Barber, N. A., Donovan, J. R., \& Dodd, T. H., 2008), (Park, K.

S., Reisinger, Y., \& Kang, H. J., 2008), (Marzo-Navarro, M., \& Pedraja-Iglesias, M., 2009), (Kolyesnikova, N., \& Dodd, T. H., 2009), (Barber, N., Taylor, D. C., \& Deale, C. S., 2010), (Bruwer, J., \& Lesschaeve, I., 2012), (Savinovic, A., Kim, S., \& Long, P., 2012), (Mikulić, J., Paunović, Z., \& Prebežac, D., 2012), (Pratt, M. A., \& Sparks, B., 2014), (Nella, A., \& Christou, E., 2014), (Cuellar, S. S., Eyler, R. C., \& Fanti, R., 2015), (Gu, Q., Qiu Zhang, H., King, B., \& Huang, S., 2018), (Canovi, M., \& Pucciarelli, F., 2019) 
The review of the papers on wine and wine tourism in the Tourism Management Perspectives is offered in the table below (Table 11.).

Table 11. The review of the papers on wine and wine tourism in Tourism Management Perspectives

\begin{tabular}{|l|l|l|l|l|}
\hline Authors & Year & Title of the paper & $\begin{array}{l}\text { Volume } \\
\text { (Issue), } \\
\text { Pages }\end{array}$ & Comment/Description \\
\hline $\begin{array}{l}\text { López- } \\
\text { Guzmán, } \\
\text { T., Vieira- } \\
\text { Rodríguez, } \\
\begin{array}{l}\text { A., \& } \\
\text { Rodríguez- } \\
\text { García, J. }\end{array}\end{array}$ & 2014 & $\begin{array}{l}\text { Profile and } \\
\text { motivations of } \\
\text { European tourists } \\
\text { on the Sherry wine } \\
\text { route of Spain }\end{array}$ & $\begin{array}{l}11, \\
63-68\end{array}$ & $\begin{array}{l}\text { "The main results of the research show } \\
\text { that the tourists are highly satisfied with } \\
\text { the winery visit, while highlighting the } \\
\text { relationship between wine, local cuisine, } \\
\text { and the growing interest of travellers } \\
\text { in everything related to wine culture." } \\
\text { (Segments - Spanish, Germans and other } \\
\text { European citizens) - Spain }\end{array}$ \\
\hline $\begin{array}{l}\text { Garibaldi, R., } \\
\text { Stone, M. J., } \\
\text { Wolf, E., \& } \\
\text { Pozzi, A. }\end{array}$ & 2017 & $\begin{array}{l}\text { Wine travel in the } \\
\text { profile of wine } \\
\text { travellers and wine } \\
\text { tours }\end{array}$ & $\begin{array}{l}23, \\
53-57\end{array}$ & $\begin{array}{l}\text { "The comparison tries to highlight critical } \\
\text { issues that may allow tour operators to enter } \\
\text { successfully a market where consumers may } \\
\text { tend to shy away from organized travels." } \\
\text { (USA) }\end{array}$ \\
\hline $\begin{array}{l}\text { Soontiens, } \\
\text { W., Dayaram, } \\
\text { K., Burgess, } \\
\text { J., \& } \\
\text { Grimstad, S. }\end{array}$ & 2018 & $\begin{array}{l}\text { Bittersweet? Urban } \\
\text { proximity and wine } \\
\text { tourism in the Swan } \\
\text { Valley Region }\end{array}$ & $\begin{array}{l}28, \\
105-112\end{array}$ & $\begin{array}{l}\text { "The study highlights how proximity to an } \\
\text { urban market can be a major challenge for } \\
\text { an industry based on agri-business in a rural } \\
\text { setting." (Swan Valley, Australia) }\end{array}$ \\
\hline
\end{tabular}

Source: The authors' research; Reviewed papers: (López-Guzmán, T., Vieira-Rodríguez, A., \& Rodríguez-García, J., 2014), (Garibaldi, R., Stone, M. J., Wolf, E., \& Pozzi, A., 2017), (Soontiens, W., Dayaram, K., Burgess, J., \& Grimstad, S., 2018)

The review of the papers on wine and wine tourism in the Asia Pacific Journal of Tourism Research is offered in the table below (Table 12.).

Table 12. The review of the papers on wine and wine tourism in Asia Pacific Journal of Tourism Research

\begin{tabular}{|l|l|l|l|l|}
\hline Authors & Year & Title of the paper & $\begin{array}{l}\text { Volume } \\
\text { (Issue), } \\
\text { Pages }\end{array}$ & Comment/Description \\
\hline $\begin{array}{l}\text { Dawson, } \\
\text { D., } \\
\begin{array}{l}\text { Fountain, J. } \\
\text { \& Cohen, } \\
\text { D. A. }\end{array}\end{array}$ & $\begin{array}{l}\text { Seasonality and } \\
\text { the Lifestyle } \\
\text { "Conundrum": } \\
\text { An Analysis } \\
\text { of Lifestyle } \\
\text { Entrepreneurship } \\
\text { in Wine Tourism } \\
\text { Regions }\end{array}$ & $\begin{array}{l}16(5), \\
551-572\end{array}$ & $\begin{array}{l}\text { "Both the wine and tourism industries are } \\
\text { regional initiatives to manage seasonality, } \\
\text { through events or marketing, particularly } \\
\text { when the businesses are small scale and } \\
\text { located in peripheral areas." }\end{array}$ \\
\hline
\end{tabular}




\begin{tabular}{|l|l|l|l|l|}
\hline Authors & Year & Title of the paper & $\begin{array}{l}\text { Volume } \\
\text { (Issue), } \\
\text { Pages }\end{array}$ & Comment/Description \\
\hline $\begin{array}{l}\text { Chen, X., } \\
\text { Goodman, } \\
\text { S., Bruwer, } \\
\text { J. \& Cohen, } \\
\text { J. }\end{array}$ & 2016 & $\begin{array}{l}\text { Beyond Better } \\
\text { Wine: The Impact } \\
\text { of Experiential and } \\
\text { Monetary Value } \\
\text { on Wine Tourists, } \\
\text { Loyalty Intentions }\end{array}$ & $\begin{array}{l}\text { 21(2), } \\
172-192\end{array}$ & $\begin{array}{l}\text { The authors associate hedonic value, utilitarian } \\
\text { value, monetary value perception with } \\
\text { satisfaction and loyalty intentions. "Cellar door } \\
\text { visitors are oriented toward the experiential } \\
\text { aspects of the visit itself as much as to } \\
\text { pragmatic considerations in purchasing wine". }\end{array}$ \\
\hline $\begin{array}{l}\text { Chong, K. } \\
\text { L. }\end{array}$ & 2017 & $\begin{array}{l}\text { Thailand wine } \\
\text { tourism: a dream or } \\
\text { a reality? }\end{array}$ & $\begin{array}{l}22(6), \\
604-614\end{array}$ & $\begin{array}{l}\text { "Wine tourism in Thailand was still an infant } \\
\text { industry as most tourists and tourism operators } \\
\text { were still not aware of the product offered. } \\
\text { However, the wineries themselves had already } \\
\text { owned the competency to serve the market." }\end{array}$ \\
\hline $\begin{array}{l}\text { Duan, B., } \\
\text { Arcodia, } \\
\text { C., Ma, E. } \\
\text { \& Hsiao, A. }\end{array}$ & 2018 & $\begin{array}{l}\text { Understanding wine } \\
\text { tourism in China } \\
\text { using an integrated } \\
\text { product-level } \\
\text { and experience } \\
\text { economy } \\
\text { framework }\end{array}$ & $\begin{array}{l}\text { 23(10), } \\
949-960\end{array}$ & $\begin{array}{l}\text { The authors found that wine tourism in China } \\
\text { was in the infancy stage, and that "core } \\
\text { product needed more customers' involvement, } \\
\text { and enrichment of the augmented product, to } \\
\text { best position the wine destinations". }\end{array}$ \\
\hline
\end{tabular}

Source: The authors' research; Reviewed papers: (Dawson, D., Fountain, J. \& Cohen, D. A., 2011), (Chen, X., Goodman, S., Bruwer, J. \& Cohen, J., 2016), (Chong, K. L., 2017), (Duan, B., Arcodia, C., Ma, E. \& Hsiao, A., 2018)

The review of the papers on wine and wine tourism in the Scandinavian Journal of Hospitality \& Tourism is offered in the table below (Table 13.).

Table 13. The review of the papers on wine and wine tourism in Scandinavian Journal of Hospitality \& Tourism

\begin{tabular}{|l|l|l|l|l|}
\hline Authors & Year & Title of the paper & $\begin{array}{l}\text { Volume (Issue), } \\
\text { Pages }\end{array}$ & Comment/Description \\
\hline $\begin{array}{l}\text { Kim, H., \& } \\
\text { Bonn, M. A. }\end{array}$ & 2015 & $\begin{array}{l}\text { The moderating effects of } \\
\text { overall and organic wine } \\
\text { knowledge on consumer } \\
\text { behavioral intention }\end{array}$ & $\begin{array}{l}\text { 15(3), } \\
295-310\end{array}$ & $\begin{array}{l}\text { Trust and taste factors influence } \\
\text { consumer behavioral intentions. } \\
\text { Also, environment factor is } \\
\text { important predictor. (USA) }\end{array}$ \\
\hline
\end{tabular}

Source: The authors' research; Reviewed papers: (Kim, H., \& Bonn, M. A., 2015)

The review of the papers on wine and wine tourism in Journal of Tourism \& Cultural Change is offered in the table below (Table 14.).

Table 14. The review of the papers on wine and wine tourism in Journal of Tourism \& Cultural Change

\begin{tabular}{|l|l|l|l|l|}
\hline Authors & Year & Title of the paper & $\begin{array}{l}\text { Volume } \\
\text { (Issue), } \\
\text { Pages }\end{array}$ & Comment/Description \\
\hline $\begin{array}{l}\text { Mazurkiewicz- } \\
\text { Pizlo, A. }\end{array}$ & 2016 & $\begin{array}{l}\text { The importance of non- } \\
\text { profit organisations in } \\
\text { developing wine tourism } \\
\text { in Poland }\end{array}$ & $\begin{array}{l}\text { 14(4), } \\
339-349\end{array}$ & $\begin{array}{l}\text { The authors found that non-profit } \\
\text { organizations play a significant role } \\
\text { in the development of winery and } \\
\text { wine tourism. (Poland) }\end{array}$ \\
\hline
\end{tabular}

Source: The authors' research; Reviewed papers: (Mazurkiewicz-Pizlo, A., 2016) 
The review of the papers on wine and wine tourism in Tourism Economics is offered in the table below (Table 15.).

Table 15. The review of the papers on wine and wine tourism in Tourism Economics

\begin{tabular}{|c|c|c|c|c|}
\hline Authors & Year & Title of the paper & $\begin{array}{l}\text { Volume } \\
\text { (Issue), } \\
\text { Pages }\end{array}$ & Comment/Description \\
\hline $\begin{array}{l}\text { Brown, M. D., } \\
\text { Var, T., \& Lee, } \\
\text { S. }\end{array}$ & 2002 & $\begin{array}{l}\text { Messina Hof Wine } \\
\text { and Jazz Festival: } \\
\text { An Economic Impact } \\
\text { Analysis }\end{array}$ & $\begin{array}{l}8(3), \\
273-279\end{array}$ & $\begin{array}{l}\text { The authors found that the "Messina } \\
\text { Hof Wine and Jazz Festival" had } \\
\text { a significant impact on total sales } \\
\text { output, personal income and jobs, } \\
\text { which led to the conclusion that the } \\
\text { festival would have a significant } \\
\text { economic impact on Brazon County. } \\
\text { (Texas, USA) }\end{array}$ \\
\hline Marques, $\mathrm{H}$. & 2006 & $\begin{array}{l}\text { Research Report: } \\
\text { Searching for } \\
\text { Complementarities } \\
\text { between Agriculture } \\
\text { and Tourism - The } \\
\text { Demarcated Wine- } \\
\text { Producing Regions of } \\
\text { Northern Portugal } \\
\end{array}$ & $\begin{array}{l}\text { 12(1), } \\
147-155\end{array}$ & $\begin{array}{l}\text { The author emphasizes the } \\
\text { importance of agritourism in the } \\
\text { development of the rural wine } \\
\text { regions of northern Portugal. (North } \\
\text { Portugal) }\end{array}$ \\
\hline $\begin{array}{l}\text { Taylor, P., } \\
\text { McRae- } \\
\text { Williams, P., \& } \\
\text { Lowe, J. }\end{array}$ & 2007 & $\begin{array}{l}\text { The Determinants } \\
\text { of Cluster Activities } \\
\text { in the Australian } \\
\text { Wine and Tourism } \\
\text { Industries }\end{array}$ & $\begin{array}{l}13(4), \\
639-656\end{array}$ & $\begin{array}{l}\text { "The study finds that industry } \\
\text { does seem to be more important } \\
\text { than place in the determination } \\
\text { of networking and cooperative } \\
\text { cluster activities, and that members } \\
\text { of the wine tourism industry } \\
\text { participate more in these activities } \\
\text { than members of the tourism or } \\
\text { hospitality industries." }\end{array}$ \\
\hline $\begin{array}{l}\text { Ohe, Y., \& } \\
\text { Ciani, A. }\end{array}$ & 2011 & $\begin{array}{l}\text { Evaluation of } \\
\text { Agritourism Activity } \\
\text { in Italy: Facility } \\
\text { Based or Local } \\
\text { Culture Based? }\end{array}$ & $\begin{array}{l}17(3), \\
581-601\end{array}$ & $\begin{array}{l}\text { "Owning a swimming pool is the } \\
\text { most common and influential factor } \\
\text { in enhancing the price level, while } \\
\text { regional diversity is observed } \\
\text { in local cultural resource based } \\
\text { activities such as restaurants, World } \\
\text { Heritage Sites and DOC wines." }\end{array}$ \\
\hline Sampaio, A. & 2012 & $\begin{array}{l}\text { Wine Tourism and } \\
\text { Visitors' Perceptions: } \\
\text { A Structural Equation } \\
\text { Modelling Approach }\end{array}$ & $\begin{array}{l}18(3), \\
533-553\end{array}$ & $\begin{array}{l}\text { "Global tourist satisfaction is } \\
\text { influenced directly by the tourists' } \\
\text { level of wine involvement and } \\
\text { indirectly by their image of Madeira } \\
\text { Island". }\end{array}$ \\
\hline
\end{tabular}




\begin{tabular}{|l|l|l|l|l|}
\hline Authors & Year & Title of the paper & $\begin{array}{l}\text { Volume } \\
\text { (Issue), } \\
\text { Pages }\end{array}$ & Comment/Description \\
\hline $\begin{array}{l}\text { Asero, V., \& } \\
\text { Tomaselli, V. }\end{array}$ & 2015 & $\begin{array}{l}\text { Research Note: } \\
\text { Analysing Tourism } \\
\text { Demand in Tourist } \\
\text { Districts - The Case } \\
\text { of Sicily }\end{array}$ & $\begin{array}{l}21(5), \\
1111-1119\end{array}$ & $\begin{array}{l}\text { "The findings highlight the } \\
\text { importance of the seaside, cultural, } \\
\text { and food and wine/nature segments. } \\
\text { The analysis of the distribution } \\
\text { of per capita per day expenditure } \\
\text { shows higher average values for the } \\
\text { cultural holiday." }\end{array}$ \\
\hline $\begin{array}{l}\text { McFarlane, } \\
\text { J., Grant, B., } \\
\begin{array}{l}\text { Blackwell, B., } \\
\text { \& Mounter, S. }\end{array}\end{array}$ & 2017 & $\begin{array}{l}\text { Combining amenity } \\
\text { with experience: } \\
\text { Exploring the hidden } \\
\text { capital of a winescape } \\
\text { experience }\end{array}$ & $\begin{array}{l}\text { 23(5), } \\
1076-1095\end{array}$ & $\begin{array}{l}\text { The authors use input-output } \\
\text { analysis to evaluate the economic } \\
\text { performance and benefits of the } \\
\text { wine industry. (Central West Region } \\
\text { of New South Wales, Australia) }\end{array}$ \\
\hline
\end{tabular}

Source: The authors' research; Reviewed papers: (Brown, M. D., Var, T., \& Lee, S., 2002), (Marques, H., 2006), (Taylor, P., McRae-Williams, P., \& Lowe, J., 2007), (Ohe, Y., \& Ciani, A., 2011), (Sampaio, A., 2012), (Asero, V., \& Tomaselli, V., 2015), (McFarlane, J., Grant, B., Blackwell, B., \& Mounter, S., 2017)

The average age of the papers (if we consider 2019 as the starting point for the calculation) is 8.41 years - Journal of Hospitality \& Tourism Research (11.27), Journal of Sustainable Tourism (10.00), Journal of Travel \& Tourism Marketing (9.75), Tourism Management (9.53), Annals of Tourism Research (9.40), Tourism Economics (9), Tourism Geographies (8), International Journal of Tourism Research (7.18), Current Issues in Tourism (5.44), Scandinavian Journal of Hospitality and Tourism (4), Asia Pacific Journal of Tourism Research (3.50), Journal of Tourism and Cultural Change (3), Tourism Management Perspectives (2.67). All previous numbers are rounded to two decimal places.

On the basis of the data obtained in the review, it is clear that the oldest paper on wine and wine tourism in the analyzed journals was published in 1989, and the latest come from the research year - 2019, indicating that the first paper was published more than three decades ago. Also, it can be observed that the number of papers was negligible until the beginning of the $21^{\text {st }}$ century ( 5 papers, $5.49 \%$ ). The progress is already obvious in the first decade of the $21^{\text {st }}$ century, when a considerable number of papers was published (34 papers, 37.36\%). So far, in the second decade of the $21^{\text {st }}$ century, 52 papers have been published, which is more than a half of the established number of the papers on wine and wine tourism $(57.14 \%)$. This fact indicates an increase in the interest in wine and wine tourism, and therefore even a larger number of the papers can be expected in the following decades. The largest number of papers was published in $2012(10 ; 10 \%)$, while there has been a regular number of papers published since 2015 (note: at the time of the research, three more papers were published (2019), and it certainly is not the final number). The review of the papers per year of publishing is offered in the following graph (Figure 1.). 
Figure 1. The review of the papers on wine and wine tourism per year of publishing

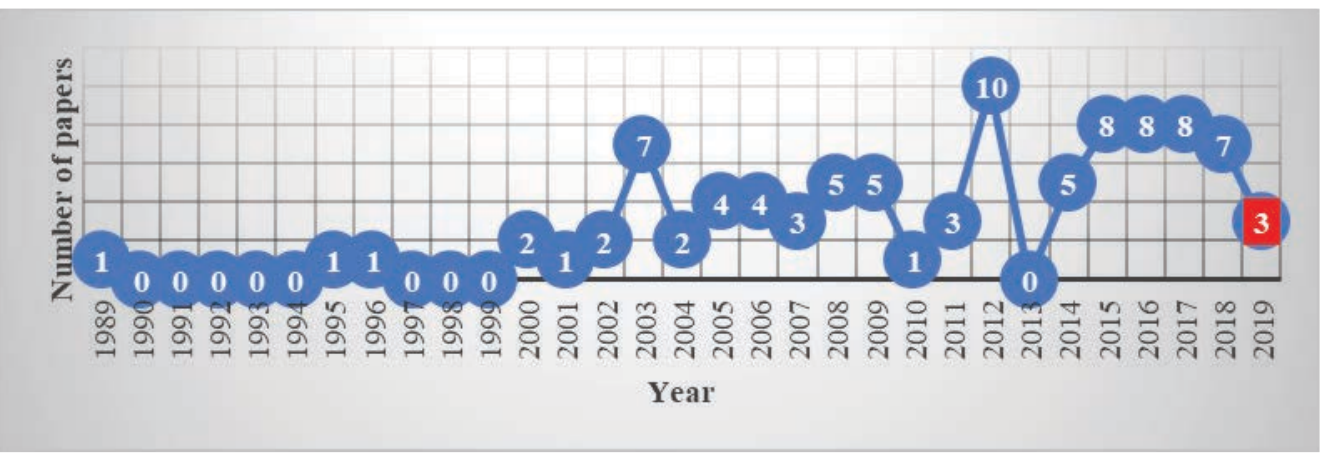

The source: the authors' research

We should mention the most often represented authors - Bruwer, J. (7 papers, 7.69\%), Alonso, A. D. (5 papers, 5.49\%), Dodd, T. H. (4 papers, 4.4\%), Getz, D. (4 papers, $4.4 \%$, etc).

Finally, the subject and aim of this paper have been achieved on the basis of the aforementioned research results on wine and wine tourism.

After determining the number of papers related to wine and wine tourism in the analyzed journals, the frequency of words in the keywords of the analyzed papers was determined. In order to better understand the distribution of keywords, it is necessary to present them by journals, by time periods and in the total number of papers.

The most frequent words in keywords by journals are given in the table below (Table 16.).

Table 16. The most frequent words in keywords (journals view)

\begin{tabular}{|l|l|}
\hline \multicolumn{1}{|c|}{ Journal } & \multicolumn{1}{|c|}{ The most frequent words in keywords } \\
\hline $\begin{array}{l}\text { Tourism } \\
\text { Management }\end{array}$ & $\begin{array}{l}\text { wine (18), tourism (16), behavioral/behaviour(s) (5), attitude(s) (4), destination } \\
\text { (3), experience(s)/experiential (3), structural (3), control (2), customer (2), } \\
\text { equation (2), influences (2), intention (2), involvement (2), marketing (2), } \\
\text { model(ling) (2), norms/normative (2), region(al) (2), theory (2), tourist(s) (2), } \\
\text { trail(s) (2), willingness (2), winescape (2) }\end{array}$ \\
\hline $\begin{array}{l}\text { Annals of Tourism } \\
\text { Research }\end{array}$ & tourism (3), cultural (2), orientations (2), wine (2) \\
\hline $\begin{array}{l}\text { Current Issues in } \\
\text { Tourism }\end{array}$ & $\begin{array}{l}\text { tourism (13), wine (12), behaviour (2), culinary (2), experience(s) (2), rural (2), } \\
\text { sustainable (2) }\end{array}$ \\
\hline $\begin{array}{l}\text { Journal of } \\
\text { Sustainable } \\
\text { Tourism }\end{array}$ & tourism (3), wine (3), sustainable (2) \\
\hline $\begin{array}{l}\text { Journal of } \\
\text { Hospitality \& } \\
\text { Tourism Research }\end{array}$ & $\begin{array}{l}\text { wine (12), marketing (4), tourism (4), consumer(s) (3), travel (3), behavior(al) } \\
\text { value(s) (2) }\end{array}$ \\
\hline
\end{tabular}




\begin{tabular}{|c|c|}
\hline Journal & The most frequent words in keywords \\
\hline $\begin{array}{l}\text { International } \\
\text { Journal of Tourism } \\
\text { Research }\end{array}$ & $\begin{array}{l}\text { wine (12), tourism (7), behaviour(al) (3), brand (3), segmentation (3), consumer } \\
\text { (2), consumption (2), cross-cultural/acculturation (2), destination (2), food (2), } \\
\text { holiday/postholiday (2), image (2), local (2), model (2), perceived (2), tourist(s) } \\
\text { (2), visitor (2), winery/wineries (2) }\end{array}$ \\
\hline $\begin{array}{l}\text { Tourism } \\
\text { Geographies }\end{array}$ & tourism (3), wine (2) \\
\hline $\begin{array}{l}\text { Journal of Travel \& } \\
\text { Tourism Marketing }\end{array}$ & $\begin{array}{l}\text { wine(s) (27), tourism (16), marketing (6), socio-/social (5), involvement (4), } \\
\text { segments/segmentation (4), tourist(s) (4), winery/wineries (4), destination (3), } \\
\text { festival(s) (3), image (3), media (3), visitor(s) (3), analysis (2), audience (2), } \\
\text { Australia(n) (2), brand (2), Chinese (2), consumer (2), food (2), France (2), } \\
\text { importance (2), market (2), motivation (2), networks/networking (2), satisfaction } \\
\text { (2), tasting (2) }\end{array}$ \\
\hline $\begin{array}{l}\text { Tourism } \\
\text { Management } \\
\text { Perspectives }\end{array}$ & tourism (4), wine (3), tourist (2) \\
\hline $\begin{array}{l}\text { Asia Pacific } \\
\text { Journal of Tourism } \\
\text { Research }\end{array}$ & tourism (5), wine (5), value (4), experience (2) \\
\hline $\begin{array}{l}\text { Scandinavian } \\
\text { Journal of } \\
\text { Hospitality \& } \\
\text { Tourism* }\end{array}$ & $\begin{array}{l}\text { organic (2), wine (2) } \\
\text { (organic wine attributes, overall and organic wine knowledge, consumer } \\
\text { behavioral intentions)** }\end{array}$ \\
\hline $\begin{array}{l}\text { Journal of Tourism } \\
\text { \& Cultural } \\
\text { Change* }\end{array}$ & (wine-tourism, non-profit organisations, rural areas, Poland) ${ }^{* *}$ \\
\hline Tourism Economics & $\begin{array}{l}\text { tourism (5), wine (4), analysis (3), model(ling) (3), agritourism (2), development } \\
\text { (2), regional (2) }\end{array}$ \\
\hline \multicolumn{2}{|c|}{$\begin{array}{l}\text { Notes: Words with a frequency } \geq 2 \text { are listed above; }{ }^{*} \text { - a journal in which there is only one paper; }{ }^{* *} \text { - } \\
\text { original keywords }\end{array}$} \\
\hline
\end{tabular}

The source: the authors' research

The most frequent words in keywords by time periods are given in the table below (Table 17.).

Table 17. The most frequent words in keywords (time periods view)

\begin{tabular}{|c|l|}
\hline $\begin{array}{c}\text { Time } \\
\text { period }\end{array}$ & \multicolumn{1}{c|}{ The most frequent words in keywords } \\
\hline 1989-2000 & consumer (3), wine (2) \\
\hline & $\begin{array}{l}\text { wine(s) (40), tourism (32), festival(s) (5), tourist(s) (5), analysis (4), behaviour(s) (4), } \\
\text { involvement (4), marketing (4), segments/segmentation (4), strategy/strategies/strategic } \\
\text { (4), theory (4), winery/wineries (4), destination (3), food (3), market (3), motivation (3), } \\
\text { Niagara (3), region(al) (3), special (3), Africa (2), attitude(s) (2), British Columbia (2), } \\
\text { Canada (2), consumer(s) (2), control (2), development (2), experience(s) (2), France (2), } \\
\text { influences (2), interest (2), knowledge (2), model(ling) (2), orientations (2), planned/ } \\
\text { planning (2), stakeholder (2), structural (2), trails (2), visits (2) }\end{array}$ \\
\hline
\end{tabular}




\begin{tabular}{|c|l|}
\hline $\begin{array}{c}\text { Time } \\
\text { period }\end{array}$ & \multicolumn{1}{c|}{ The most frequent words in keywords } \\
\hline \multirow{3}{*}{ 2011-2019 } & $\begin{array}{l}\text { wine (61), tourism (47), behavio(u)r(al) (10), experience(s)/experiential (9), destination } \\
\text { (8), marketing (8), model(ling) (8), tourist(s) (8), intention(s) (7), value(s) (7), brand(ing) } \\
\text { (6), cultural/cross-cultural/acculturation (6), image (6), visitor(s) (6), winery/wineries } \\
\text { (6), winescape (6), perceived (5), satisfaction (5), segments/segmentation (5), social (5), } \\
\text { travel (5), analysis (4), Australia(n) (4), benefits (4), China('s)/Chinese (4), consumer (4), } \\
\text { involvement (4), region(al) (4), rural (4), servicescape (4), sustainable (4), added/adding } \\
\text { (2), area(s) (2), attitude(s) (2), attribute(-,s) (2), audience (2), challenges (2), constraints } \\
\text { (2), cross- (2), culinary (2), customer (2), effect (2), entrepreneurs/entrepreneurship } \\
\text { (2), equation (2), equity (2), experimental/quasi-experiments (3), heritage (2), hodenic } \\
\text { (2), importance (2), industry (2), Italy (2), logistic (2), loyalty (2), mapping/maps (2), } \\
\text { networks/networking (2), norm(s) (2), organic (2), product (2), quality (2), regression } \\
\text { (2), revisit/re-visit (2), SEM (2), structural (2), subjective (2), supply (2), system(s) (2), } \\
\text { theory (2), US/USA (2), willingness (2) }\end{array}$ \\
\hline
\end{tabular}

The source: the authors' research

After reviewing (key)words frequency by journals and time periods, the (key)words view should be given for the total number of papers. The most frequent words in keywords are overall: wine(s) (103), tourism (80), behavio(u)r(ial) (15), tourist(s) (13), marketing (12), destination (11), experience(s)/experient(i)al (11), model(ling) (10), winery/wineries (10), consumer(s) (9), segments/segmentation (9), analysis (8), brand(ing) (8), involvement (8), food (7), image (7), intention(s) (7), region(al) (7), value(s) (7), visitor(s) (7), cultural/ cross-cultural/acculturation (6), festival(s) (6), motivation (6), socio-/social (6), theory (6), travel (6), winescape (6), Australia(n) (5), development (5), perceived (5), rural (5), sustainable (5). Note: Words with a frequency $\geq 5$ are listed above.

\section{Conclusions}

As it is obvious from the review of the papers on wine and wine tourism, this field is represented in 13/15 analyzed journals, whereas the total number of papers is 91 . The papers appear in the range from 1989 to 2019 (as the year of the research), whereas the greatest share was published in the $21^{\text {st }}$ century $(86 ; 94.51 \%)$, especially in its second decade (52; $57.14 \%)$ - most of them in $2012(10 ; 10 \%)$. There has been a continuous flow in the number of the papers published since 2015; therefore, on the basis of the aforementioned data, it can be concluded that that the tendency of writing the scientific papers in the field of wine and wine tourism in the journals as the subject of the analysis will continue, increasing the annual number of papers in the following decades. Also, this paper gives highlights of the contribution of these analyzed papers, the most frequent authors, and presents the frequency of words in the keywords listed in analyzed papers. On the basis of all these facts, we can infer that the subject and aim of this paper have been achieved.

The contribution of this paper is in the review of the papers dealing with the topic of wine and wine tourism published in the most important journals in the world in the field of tourism so far (journals from JCR list with Impact Factor (IF) which names refer directly 
to the word "tourism"- (Clarivate Analytics, 2018)). This is the way of creating the basis for further analyses and studies in this field for the interested scientists and researchers.

Potential disadvantages of this paper lay in the analysis of the journals (not other types of publications), more precisely a certain number of journals (15) in the field of tourism (journals from JCR list with Impact Factor (IF) which names refer directly to the word "tourism"- (Clarivate Analytics, 2018), regardless of the papers on the subject of wine and wine tourism published in other journals of the same category (rank), but in other scientific fields. Also, the analysis referred to the presence of the phrases related to wine and wine tourism in the paper titles, keywords and abstracts, not excluding the possibility (although a small one) that some of the authors were dealing with a similar analysis in the text of the paper, without stating it in the elements of this analysis (title, keywords, abstract).

Further research could be directed towards the analysis of the rest of the publications available, the other significant journals in the field of tourism (but potentially the other "related" scientific fields as well) in order to acquire a more complete picture about the studies on the role of wine and wine tourism in the complete economic movements.

In addition to all that, wine tourism will still attract people in the future, and therefore its further study will be important in order to use the potentials of this type of tourism as completely as possible.

\section{Conflict of interests}

The authors declare no conflict of interest.

\section{References}

1. 3rd UNWTO Global Conference on Wine Tourism, 6-7 September 2018, Chisinau, Moldova, http://affiliatemembers.unwto.org/event/3rd-unwto-global-conferencewine-tourism (July 11, 2019).

2. Alamanos, E., Kuznesof, S., \& Ritson, C. (2016). The influence of holidays on wine purchasing behaviour: marketing and tourism insights based on a holiday experience in Greece. International Journal of Tourism Research, 18(3), 228-235. https://doi.org/10.1002/jtr.1999

3. Alonso, A. D. \& Liu, Y. (2012). Old wine region, new concept and sustainable development: winery entrepreneurs' perceived benefits from wine tourism on Spain's Canary Islands. Journal of Sustainable Tourism, 20(7), 991-1009. DOI: 10.1080/09669582.2011.651220

4. Alonso, A. D., \& Liu, Y. (2012). Visitor Centers, Collaboration, and the Role of Local Food and Beverage as Regional Tourism Development Tools: The Case of the Blackwood River Valley in Western Australia. Journal of Hospitality \& Tourism Research, 36(4), 517-536. https://doi.org/10.1177/1096348011413594 
5. Alonso, A. D., Bressan, A., O’Shea, M., \& Krajsic, V. (2015). Perceived benefits and challenges to wine tourism involvement: An international perspective. International Journal of Tourism Research, 17(1), 66-81. https://doi.org/10.1002/ jtr. 1967

6. Asero, V., \& Tomaselli, V. (2015). Research Note: Analysing Tourism Demand in Tourist Districts - The Case of Sicily. Tourism Economics, 21(5), 1111-1119. https://doi.org/10.5367/te.2014.0392

7. Barber, N. A., Donovan, J. R., \& Dodd, T. H. (2008). Differences in tourism marketing strategies between wineries based on size or location. Journal of Travel \& Tourism Marketing, 25(1), 43-57. DOI: 10.1080/10548400802164889

8. Barber, N., Taylor, D. C., \& Deale, C. S. (2010). Wine tourism, environmental concerns, and purchase intention. Journal of Travel \& Tourism Marketing, 27(2), 146-165. DOI: $10.1080 / 10548400903579746$

9. Brown, G. P., Havitz, M. E., \& Getz, D. (2007). Relationship between wine involvement and wine-related travel. Journal of Travel \& Tourism Marketing, 21(1), 31-46. DOI: $\underline{10.1300 / J 073 v 21 n 0103}$

10. Brown, M. D., Var, T., \& Lee, S. (2002). Messina Hof Wine and Jazz Festival: An Economic Impact Analysis. Tourism Economics, 8(3), 273-279. https://doi. org/10.5367/000000002101298115

11. Bruwer, J. (2003). South African wine routes: some perspectives on the wine tourism industry's structural dimensions and wine tourism product. Tourism management, 24(4), 423-435. https://doi.org/10.1016/S0261-5177(02)00105-X

12. Bruwer, J. (2014). Service quality perception and satisfaction: Buying behaviour prediction in an Australian Festivalscape. International Journal of Tourism Research, 16(1), 76-86. https://doi.org/10.1002/jtr.1901

13. Bruwer, J., \& Lesschaeve, I. (2012). Wine tourists' destination region brand image perception and antecedents: Conceptualization of a winescape framework. Journal of Travel \& Tourism Marketing, 29(7), 611-628. DOI: $\underline{10.1080 / 10548408.2012 .719819}$

14. Bruwer, J., Pratt, M. A., Saliba, A. \& Hirche, M. (2017). Regional destination image perception of tourists within a winescape context. Current Issues in Tourism, 20(2), 157-177. DOI: $\underline{10.1080 / 13683500.2014 .904846}$

15. Bruwer, J., Prayag, G., \& Disegna, M. (2018). Why wine tourists visit cellar doors: Segmenting motivation and destination image. International Journal of Tourism Research, 20(3), 355-366. https://doi.org/10.1002/jtr.2187

16. Byrd, E. T., Canziani, B., Hsieh, Y. C. J., Debbage, K., \& Sonmez, S. (2016). Wine tourism: Motivating visitors through core and supplementary services. Tourism Management, 52, 19-29. https://doi.org/10.1016/j.tourman.2015.06.009

17. Canovi, M., \& Pucciarelli, F. (2019). Social media marketing in wine tourism: winery owners' perceptions. Journal of Travel \& Tourism Marketing, 36(6), 653664. DOI: $10.1080 / 10548408.2019 .1624241$

18. Carlsen, J., \& Boksberger, P. (2015). Enhancing Consumer Value in Wine Tourism. Journal of Hospitality \& Tourism Research, 39(1), 132-144. https://doi. org/10.1177/1096348012471379 
19. Carlsen, P. J. (2004). A review of global wine tourism research. Journal of wine research, 15(1), 5-13. DOI: 10.1080/0957126042000300281

20. Carmichael, B. (2005). Understanding the wine tourism experience for winery visitors in the Niagara region, Ontario, Canada. Tourism Geographies, 7(2), 185204. DOI: $10.1080 / 14616680500072414$

21. Charters, S., \& Ali-Knight, J. (2002). Who is the wine tourist?. Tourism management, 23(3), 311-319. https://doi.org/10.1016/S0261-5177(01)00079-6

22. Charters, S., \& Menival, D. (2011). Wine Tourism in Champagne. Journal of Hospitality \& Tourism Research, 35(1), 102-118. https://doi. org/10.1177/1096348010384597

23. Chen, X., Goodman, S., Bruwer, J. \& Cohen, J. (2016). Beyond Better Wine: The Impact of Experiential and Monetary Value on Wine Tourists' Loyalty Intentions. Asia Pacific Journal of Tourism Research, 21(2), 172-192. DOI: 10.1080/10941665.2015.1029955

24. Cho, M., Bonn, M. A., \& Brymer, R. A. (2017). A Constraint-Based Approach to Wine Tourism Market Segmentation. Journal of Hospitality \& Tourism Research, 41(4), 415-444. https://doi.org/10.1177/1096348014538049

25. Chong, K.L.(2017) Thailandwine tourism: a dreamorareality?.Asia Pacific Journal of Tourism Research, 22(6), 604-614. DOI: 10.1080/10941665.2017.1308389

26. Clarivate Analytics (2018). 2018 Journal Citation Reports, Journals in the 2018 release of JCR. https://clarivate.com/wp-content/uploads/2018/06/Crv_JCR_FullMarketing-List_A4_2018_v4.pdf

27. Cuellar, S. S., Eyler, R. C., \& Fanti, R. (2015). Experiential marketing and long-term sales. Journal of Travel \& Tourism Marketing, 32(5), 534-553. DOI: $\underline{10.1080 / 10548408.2014 .918925}$

28. Cvijanović, D. \& Ružić, P. (2017). Rural tourism. Faculty of Hotel Management and Tourism in Vrnjačka Banja, University in Kragujevac, Vrnjačka Banja. [In Serbian: Cvijanović, D. \& Ružić, P. (2017). Ruralni turizam. Fakultet za hotelijerstvo i turizam u Vrnjačkoj Banji, Univerzitet u Kragujevcu, Vrnjačka Banja.].

29. Dawson, D., Fountain, J. \& Cohen, D. A. (2011). Seasonality and the Lifestyle "Conundrum": An Analysis of Lifestyle Entrepreneurship in Wine Tourism Regions. Asia Pacific Journal of Tourism Research, 16(5), 551-572. DOI: $\underline{10.1080 / 10941665.2011 .597580}$

30. Demhardt, I. J. (2003). Wine and Tourism at the "Fairest Cape" Post-Apartheid Trends in the Western Cape Province and Stellenbosch (South Africa). Journal of Travel \& Tourism Marketing, 14(3-4), 113-130. DOI: 10.1300/J073v14n03 07

31. Dodd, T. H. (1996). Factors that Influence the Adoption and Diffusion of New Wine Products. Hospitality Research Journal, 20(3), 123-136. https://doi. org/10.1177/109634809602000308

32. Dodd, T. H., Laverie, D. A., Wilcox, J. F., \& Duhan, D. F. (2005). Differential Effects of Experience, Subjective Knowledge, and Objective Knowledge on Sources of Information used in Consumer Wine Purchasing. Journal of Hospitality \& Tourism Research, 29(1), 3-19. https://doi.org/10.1177/1096348004267518 
33. Duan, B., Arcodia, C., Ma, E. \& Hsiao, A. (2018). Understanding wine tourism in China using an integrated product-level and experience economy framework. Asia Pacific Journal of Tourism Research, 23(10), 949-960. DOI: 10.1080/10941665.2018.1512506

34. Duarte Alonso, A., Bressan, A., O’Shea, M. \& Krajsic, V. (2014). Educating winery visitors and consumers: an international perspective. Current Issues in Tourism, 17(6), 539-556. DOI: $\underline{10.1080 / 13683500.2012 .746650}$

35. Eustice, C., McCole, D., \& Rutty, M. (2019). The impact of different product messages on wine tourists' willingness to pay: A non-hypothetical experiment. Tourism Management, 72, 242-248. https://doi.org/10.1016/j.tourman.2018.11.022

36. Ferreira, S. L., \& Hunter, C. A. (2017). Wine tourism development in South Africa: a geographical analysis. Tourism Geographies, 19(5), 676-698. DOI: $\underline{10.1080 / 14616688.2017 .1298152}$

37. Fox, M. (1989). Quality Assurance and Sensory Evaluation in Foodservice - a New Course for Foodservice Managers. Hospitality Education and Research Journal, 13(3), 554-554. https://doi.org/10.1177/109634808901300366

38. Frochot, I. (2003). An analysis of regional positioning and its associated food images in French tourism regional brochures. Journal of Travel \& Tourism Marketing, 14(3-4), 77-96. DOI: 10.1300/J073v14n03 05

39. Galloway, G., Mitchell, R., Getz, D., Crouch, G., \& Ong, B. (2008). Sensation seeking and the prediction of attitudes and behaviours of wine tourists. Tourism Management, 29(5), 950-966. https://doi.org/10.1016/j.tourman.2007.11.006

40. Garibaldi, R., Stone, M. J., Wolf, E., \& Pozzi, A. (2017). Wine travel in the United States: A profile of wine travellers and wine tours. Tourism management perspectives, 23, 53-57. https://doi.org/10.1016/j.tmp.2017.04.004

41. Getz, D., \& Brown, G. (2006). Critical success factors for wine tourism regions: a demand analysis. Tourism management, 27(1), 146-158. https://doi.org/10.1016/j. tourman.2004.08.002

42. Gómez, M., \& Molina, A. (2012). Wine tourism in Spain: denomination of origin effects on brand equity. International journal of tourism research, 14(4), 353-368. https://doi.org/10.1002/jtr.868

43. Gomez, M., Lopez, C., \& Molina, A. (2015). A model of tourism destination brand equity: The case of wine tourism destinations in Spain. Tourism Management, 51, 210-222. https://doi.org/10.1016/j.tourman.2015.05.019

44. Gómez, M., Pratt, M. A., \& Molina, A. (2018). Wine tourism research: a systematic review of 20 vintages from 1995 to 2014. Current Issues in Tourism, 1-39. DOI: $10.1080 / 13683500.2018 .1441267$

45. Gross, M. J., \& Brown, G. (2008). An empirical structural model of tourists and places: Progressing involvement and place attachment into tourism. Tourism management, 29(6), 1141-1151. https://doi.org/10.1016/j.tourman.2008.02.009

46. Gu, Q., \& Huang, S. (2019). Profiling Chinese wine tourists by wine tourism constraints: A comparison of Chinese Australians and long $\square$ haul Chinese tourists in Australia. International Journal of Tourism Research, 21(2), 206-220. https:// doi.org/10.1002/jtr.2255 
47. Gu, Q., Qiu Zhang, H., King, B., \& Huang, S. (2018). Wine tourism involvement: a segmentation of Chinese tourists. Journal of travel \& tourism marketing, 35(5), 633-648. DOI: 10.1080/10548408.2017.1401031

48. Hall, C. M. (2005). Biosecurity and wine tourism. Tourism management, 26(6), 931-938. https://doi.org/10.1016/j.tourman.2004.06.011

49. Hall, C. M. (2011). Publish and perish? Bibliometric analysis, journal ranking and the assessment of research quality in tourism. Tourism Management, 32(1), 16-27, https://doi.org/10.1016/j.tourman.2010.07.001

50. Hall, C. M., Longo, A. M., Mitchell, R., \& Johnson, G. (1996, December). Wine tourism in new Zealand. In Proceedings of tourism down under II: A research conference (pp. 109-119). Dunedin: University of Otago.

51. Hashimoto, A., \& Telfer, D. J. (2003). Positioning an emerging wine route in the Niagara region: Understanding the wine tourism market and its implications for marketing. Journal of Travel \& Tourism Marketing, 14(3-4), 61-76. DOI: $10.1300 /$ J073v14n03 04

52. Hassanli, N. \& Ashwell, J. (2018). The contribution of small accommodations to a sustainable tourism industry. Current Issues in Tourism, DOI: $\underline{10.1080 / 13683500.2018 .1530201}$

53. Hjalager, A. M., \& Corigliano, M. A. (2000). Food for tourists - determinants of an image. International journal of tourism research, 2(4), 281-293. https://doi. org/10.1002/1522-1970(200007/08)2:4<281::AID-JTR228>3.0.CO;2-Y

54. Ignatov, E. \& Smith, S. (2006). Segmenting Canadian Culinary Tourists. Current Issues in Tourism, 9(3), 235-255. DOI: $10.2167 / \mathrm{cit} / 229.0$

55. International Organisation of Vine and Wine (2017). INTERNATIONAL CODE OF CENOLOGICAL PRACTICES, OIV Code Sheet - Issue 2017/01, http://www. oiv.int/public/medias/5119/code-2017-en.pdf, 11.07.2019., 10:03.

56. International Organisation of Vine and Wine (2019). STATE OF THE VITIVINICULTURE WORLD MARKET, State of the sector in 2018, april 2019, Retrived from http://www.oiv.int/public/medias/6679/en-oiv-state-of-thevitiviniculture-world-market-2019.pdf (July 11, 2019).

57. International Organisation of Vine and Wine (OIV), Retrived from http://www.oiv. int/en/statistiques/recherche (July 10, 2019).

58. Jaffe, E., \& Pasternak, H. (2004). Developing wine trails as a tourist attraction in Israel. International Journal of Tourism Research, 6(4), 237-249. https://doi. org/10.1002/jtr.485

59. Jones, M. F., Singh, N., \& Hsiung, Y. (2015). Determining the critical success factors of the wine tourism region of Napa from a supply perspective. International Journal of Tourism Research, 17(3), 261-271. https://doi.org/10.1002/jtr.1984

60. Kim, H., \& Bonn, M. A. (2015). The moderating effects of overall and organic wine knowledge on consumer behavioral intention. Scandinavian Journal of Hospitality and Tourism, 15(3), 295-310. DOI: 10.1080/15022250.2015.1007083 
61. Kolyesnikova, N., \& Dodd, T. H. (2009). There is no such thing as a free wine tasting: The effect of a tasting fee on obligation to buy. Journal of Travel \& Tourism Marketing, 26(8), 806-819. DOI: 10.1080/10548400903356228

62. Lee, K., Zhao, J., \& Ko, J.-Y. (2005). Exploring the Korean Wine Market. Journal of Hospitality \& Tourism Research, 29(1), 20-41. https://doi. org/10.1177/1096348004268195

63. Lee, S., Bruwer, J., \& Song, H. (2017). Experiential and involvement effects on the Korean wine tourist's decision-making process. Current Issues in Tourism, 20(12), 1215-1231. DOI: 10.1080/13683500.2015.1050362

64. López-Guzmán, T., García, J. R., \& Rodríguez, Á. V. (2013). REVIEW OF THE SCIENTIFIC LITERATURE ON WINE TOURISM IN SPAIN. Cuadernos de Turismo, 32, 323-326

65. López-Guzmán, T., Vieira-Rodríguez, A., \& Rodríguez-García, J. (2014). Profile and motivations of European tourists on the Sherry wine route of Spain. Tourism Management Perspectives, 11, 63-68. https://doi.org/10.1016/j.tmp.2014.04.003

66. March, R., \& Wilkinson, I. (2009). Conceptual tools for evaluating tourism partnerships. Tourism management, 30(3), 455-462. https://doi.org/10.1016/j. tourman.2008.09.001

67. Marques, H. (2006). Research Report: Searching for Complementarities between Agriculture and Tourism - The Demarcated Wine-Producing Regions of Northern Portugal. Tourism Economics, 12(1), 147-155. https://doi. org/10.5367/000000006776387141

68. Marzo $\square$ Navarro, M., \& Pedraja $\square$ Iglesias, M. (2009). Profile of a wine tourist and the correspondence between destination and preferred wine: A study in Aragon, Spain. Journal of Travel \& Tourism Marketing, 26(7), 670-687. DOI: 10.1080/10548400903281251

69. Mason, M. C., \& Paggiaro, A. (2012). Investigating the role of festivalscape in culinary tourism: The case of food and wine events. Tourism management, 33(6), 1329-1336. https://doi.org/10.1016/j.tourman.2011.12.016

70. Mazurkiewicz-Pizlo, A. (2016). The importance of non-profit organisations in developing wine tourism in Poland. Journal of Tourism and Cultural Change, 14(4), 339-349. DOI: 10.1080/14766825.2015.1102922

71. McFarlane, J., Grant, B., Blackwell, B., \& Mounter, S. (2017). Combining amenity with experience: Exploring the hidden capital of a winescape experience. Tourism Economics, 23(5), 1076-1095. https://doi.org/10.1177/1354816616665754

72. Mikulić, J., Paunović, Z., \& Prebežac, D. (2012). An extended neural network-based importance-performance analysis for enhancing wine fair experience. Journal of Travel \& Tourism Marketing, 29(8), 744-759. DOI: $\underline{10.1080 / 10548408.2012 .730936}$

73. Mitchell, R. D., \& Hall, C. M. (2003). Seasonality in New Zealand winery visitation: An issue of demand and supply. Journal of Travel \& Tourism Marketing, 14(3-4), 155-173. DOI: $10.1300 / \mathrm{J} 073 \mathrm{v} 14 \mathrm{n} 03 \quad 09$

74. Mitchell, R., \& Hall, C. M. (2006). Wine tourism research: the state of play. Tourism ReviewInternational,9(4),307-332.https://doi.org/10.3727/154427206776330535 
75. Mitchell, R., Charters, S., \& Albrecht, J. N. (2012). Cultural systems and the wine tourism product. Annals of tourism research, 39(1), 311-335. https://doi. org/10.1016/j.annals.2011.05.002

76. Montella, M. (2017). Wine tourism and sustainability: A review. Sustainability, 9(1), 1-11

77. Moore, R. S. (1995). Gender and alcohol use in a Greek tourist town. Annals of Tourism Research, 22(2), 300-313. https://doi.org/10.1016/0160-7383(94)00078-6

78. Nella, A., \& Christou, E. (2014). Segmenting wine tourists on the basis of involvement with wine. Journal of Travel \& Tourism Marketing, 31(7), 783-798. DOI: $\underline{10.1080 / 10548408.2014 .889639}$

79. Ohe, Y., \& Ciani, A. (2011). Evaluation of Agritourism Activity in Italy: Facility Based or Local Culture Based? Tourism Economics, 17(3), 581-601. https://doi. org/10.5367/te.2011.0048

80. Park, K. S., Reisinger, Y., \& Kang, H. J. (2008). Visitors' motivation for attending the South Beach wine and food festival, Miami Beach, Florida. Journal of Travel \& Tourism Marketing, 25(2), 161-181. DOI: $\underline{\text { 10.1080/10548400802402883 }}$

81. Poitras, L. \& Donald, G. (2006). Sustainable Wine Tourism: The Host Community Perspective. Journal of Sustainable Tourism, 14(5), 425-448. DOI: $10.2167 /$ jost587.0

82. Popp, L. \& McCole, D. (2016). Understanding tourists' itineraries in emerging rural tourism regions: the application of paper-based itinerary mapping methodology to a wine tourism region in Michigan. Current Issues in Tourism, 19(10), 988-1004. DOI: $\underline{10.1080 / 13683500.2014 .942259}$

83. Pratt, M. A., \& Sparks, B. (2014). Predicting wine tourism intention: Destination image and self-congruity. Journal of Travel \& Tourism Marketing, 31(4), 443-460. DOI: $\underline{10.1080 / 10548408.2014 .883953}$

84. Quintal, V. A., Thomas, B., \& Phau, I. (2015). Incorporating the winescape into the theory of planned behaviour: Examining 'new world' wineries. Tourism Management, 46, 596-609. https://doi.org/10.1016/j.tourman.2014.08.013

85. Rabbiosi, C. (2016). Place branding performances in tourist local food shops. Annals of tourism research, 60, 154-168. https://doi.org/10.1016/j.annals.2016.07.002

86. Rutherford, D. G., Perkins, A. W., \& Spangenberg, E. R. (2000). Trade Dress and Consumer Perception of Product Similarity. Journal of Hospitality \& Tourism Research, 24(2), 163-179. https://doi.org/10.1177/109634800002400203

87. Saayman, M., Krugell, W. F., \& Saayman, A. (2016). Willingness to pay: Who are the cheap talkers?.Annals of Tourism Research, 56,96-111.https://doi.org/10.1016/j.annals.2015.11.009

88. SAGE Journals, https://journals.sagepub.com/ (July 6, 2019)

89. Sampaio, A. (2012). Wine Tourism and Visitors' Perceptions: A Structural Equation Modelling Approach. Tourism Economics, 18(3), 533-553. https://doi. org/10.5367/te.2012.0132

90. Sánchez, A. D., Del Río, M. D. L. C., \& García, J. Á. (2017). Bibliometric analysis of publications on wine tourism in the databases Scopus and WoS. European Research on Management and Business Economics, 23(1), 8-15. https://doi. org/10.1016/j.iedeen.2016.02.001 
91. Sánchez, A. D., García, J. Á., \& del Río, M. D. L. C. (2016). Wine tourism: scientific literature analysis in cross-cultural research of doctoral thesis. Estudios y Perspectivas en Turismo, 25(2), 186-202. [In Spanish: Sánchez, A. D., García, J. Á., \& del Río, M. D. L. C. (2016). Análisis de la literatura científica en las investigaciones transculturales de tesis doctorales en enoturismo. Estudios y perspectivas en turismo, 25(2), 186-202.].

92. Savinovic, A., Kim, S., \& Long, P. (2012). Audience members' motivation, satisfaction, and intention to re-visit an ethnic minority cultural festival. Journal of Travel \& Tourism Marketing,29(7), 682-694.DOI: 10.1080/10548408.2012.720154

93. Scherrer, P., Alonso, A., \& Sheridan, L. (2009). Expanding the destination image: Wine tourism in the Canary Islands. International journal of tourism research, 11(5), 451-463. https://doi.org/10.1002/jtr.713

94. ScienceDirect, http://www.sciencedirect.com/ (July 6, 2019)

95. Shanka, T. \& Taylor, R. (2004). Discriminating Factors of First-time and Repeat Visitors to Wine Festivals. Current Issues in Tourism, 7(2), 134-145. DOI: $\underline{10.1080 / 13683500408667976}$

96. Soontiens, W., Dayaram, K., Burgess, J., \& Grimstad, S. (2018). Bittersweet? Urban proximity and wine tourism in the Swan Valley Region. Tourism management perspectives, 28, 105-112. https://doi.org/10.1016/j.tmp.2018.08.008

97. Sparks, B. (2007). Planning a wine tourism vacation? Factors that help to predict tourist behavioural intentions. Tourism management, 28(5), 1180-1192. https:// doi.org/10.1016/i.tourman.2006.11.003

98. Stavrinoudis, T. A., Tsartas, P., \& Chatzidakis, G. (2012). Study of the major supply factors and business choices affecting the growth rate of wine tourism in Greece. Current Issues in Tourism, 15(7), 627-647. DOI: 10.1080/13683500.2011.630457

99. Taylor \& Francis Online, https://www.tandfonline.com (July 6 and 7, 2019)

100. Taylor, P., McRae-Williams, P., \& Lowe, J. (2007). The Determinants of Cluster Activities in the Australian Wine and Tourism Industries. Tourism Economics, 13(4), 639-656. https://doi.org/10.5367/000000007782696050

101. Telfer, D. J. (2001). Strategic alliances along the Niagara wine route. Tourism Management, 22(1), 21-30. https://doi.org/10.1016/S0261-5177(00)00033-9

102. Thomas, B., Quintal, V. A., \& Phau, I. (2018). Wine Tourist Engagement With the Winescape: Scale Development and Validation. Journal of Hospitality \& Tourism Research, 42(5), 793-828. https://doi.org/10.1177/1096348016640583

103. Westering, J. V., \& Niel, E. (2003). The organization of wine tourism in France: The involvement of the French public sector. Journal of Travel \& Tourism Marketing, 14(3-4), 35-47. DOI: $10.1300 / J 073 v 14 n 03 \_02$

104. White, C. J., \& Thompson, M. (2009). Self determination theory and the wine club attribute formation process. Annals of Tourism Research, 36(4), 561-586. https:// doi.org/10.1016/j.annals.2009.04.001

105. Wiley Online Library, https://onlinelibrary.wiley.com/ (July 7, 2019) 
106. Williams, P. W., \& Dossa, K. B. (2003). Non-resident wine tourist markets: Implications for British Columbia's emerging wine tourism industry. Journal of Travel \& Tourism Marketing, 14(3-4), 1-34. DOI: 10.1300/J073v14n03_01

107. Xu, S., Barbieri, C., Anderson, D., Leung, Y. F., \& Rozier-Rich, S. (2016). Residents' perceptions of wine tourism development. Tourism Management, 55, 276-286. https://doi.org/10.1016/j.tourman.2016.02.016

108. Ye, B. H., Zhang, H. Q., \& Yuan, J. (2017). Intentions to Participate in Wine Tourism in an Emerging Market: Theorization and Implications. Journal of Hospitality \& Tourism Research, 41(8), 1007-1031. https://doi.org/10.1177/1096348014525637

109. Yuan, J., Morrison, A. M., Cai, L. A., \& Linton, S. (2008). A model of wine tourist behaviour: a festival approach. International Journal of Tourism Research, 10(3), 207-219. https://doi.org/10.1002/jtr.651 